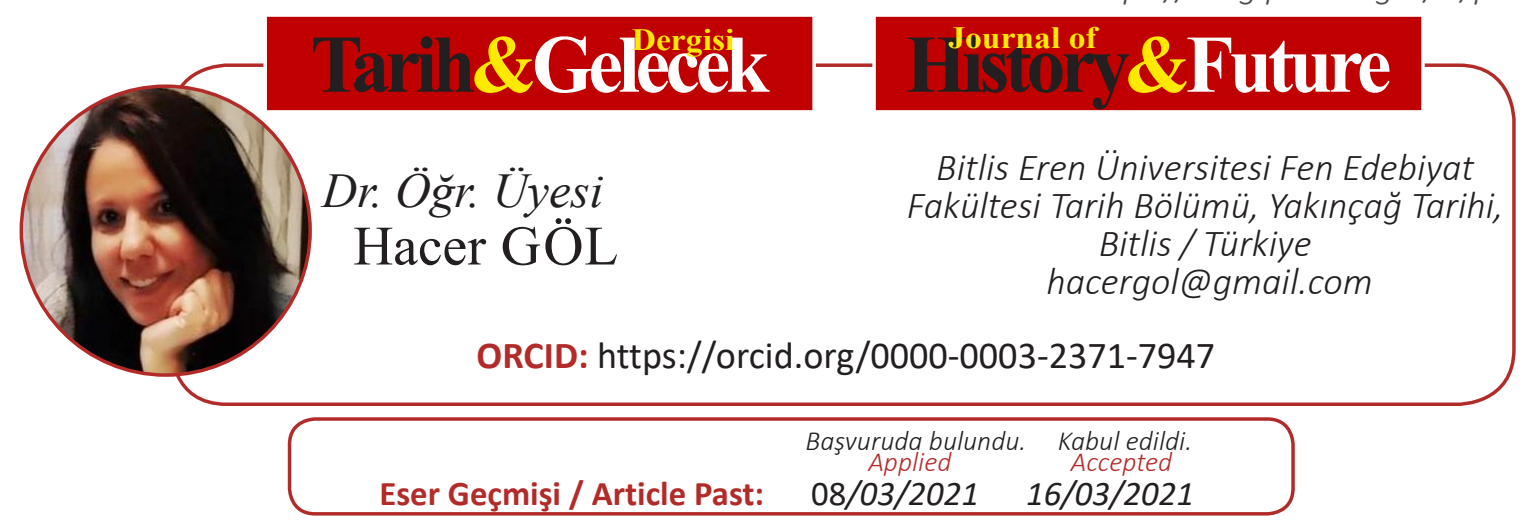

Araştırma Makalesi

DOI: http://dx.doi.org/10.21551/jhf.892783

Research Paper

Orjinal Makale / Orginal Paper

\title{
Belgelerle Mahmut Şevket Paşa Suikastı
}

\author{
The Assassination of Mahmut Şevket Pasha with Documents
}

\section{Öz}

Mahmut Şevket Paşa, Osmanlı Sadrazamı ve Harbiye Nazırı'dır. Tarih içerisinde hem askeri hem de siyasi yönden birçok eleştirilere maruz kalmıştır. Askeri açıdan Arnavut İsyanları sırasındaki sert tavrı, Trablusgarp ve Balkan Savaşları sırasında aldığı kararlar, siyasi açıdan ise İttihat ve Terakki Fırkası ile ilişkileri tartışılmıştır. Onun meclis ve mebuslar üzerinde de baskın bir kişiliği vardır. İttihat ve Terakki Fırkası'na yakın tavrı nedeniyle İttihatçı olarak algılanmış ve 11 Haziran 1913 'te otomobili ile Harbiye Nezareti’nden Babıali'deki görevine giderken bir suikasta uğramış, kısa süre içerisinde de hayatını kaybetmiştir.

İttihat ve Terakki Fırkası, Mahmut Şevket Paşa suikastını siyasi bir firsat olarak değerlendirmiştir. Rakiplerinin bir kısmını bu suikast ile ilişkilendirerek cezalandırmışlar ve İstanbul' dan uzaklaştırmışlardır. Osmanlı Tarihi açısından ilk planlı suikast girişimi olarak da nitelendirilen bu suikasta farklı kesim ve görüşten pek çok kişi katılmıştır. Siyasi, askeri pek çok kişi yanında İttihat ve Terakki iktidarı döneminde istekleri gerçekleşmeyen kişisel ya da ailevi nedenlerle bu suikasta destek verenlerin de olduğu görülmüştür. Prens Sabahattin, Şerif Paşa ve Damat Salih Paşa gibi önemli kişiler özellikle maddi destek anlamında suikastçılarla işbirliğine girmişlerdir. Suikastçılar, dönemin büyük devletlerinden olan Avusturya ile İstanbul'daki diğer sefarethanelere suikastın yapılacağı gün gönderilen beyannamelerle askerlerini İstanbul'daki gemilerden indirmeleri ve olaya müdahale etmelerini de istemişlerdir. $\mathrm{Bu}$ suikast İttihatçıların Babıali Baskını’na karşı hamle olarak da değerlendirilmiştir. İttihatçılara muhalif olan Hürriyet ve İtilaf Fırkası'nın pek çok ferdi de suikastı desteklemiştir. Damat Salih Paşa'nın bu suikast sonucu idam edilmesi ise hanedan ailesi içerisinde tepkilere neden olmuştur. İttihatçılar her ne olursa olsun kendilerine yönelik bu tür girişimlere taviz vermeyeceklerini sert tavırları ile göstermişlerdir. Suikast ile ilişkilendirilen pek çok kişi idama mahkûm edilmiş, kalebentlikle cezalandırılmış ya da sürgüne gönderilmiştir.

ATIF: GÖL, Hacer, “Belgelerle Mahmut Şevket Paşa Suikastı”, Tarih ve Gelecek Dergisi, 7/1 (Mart 2021), s. (334-362) 
Mahmut Şevket Paşa suikastı, sonuçları bakımından siyasi tarihimizde önemli bir yer işgal eder. Aslında sadece Mahmut Şevket Paşa'nın değil Talat ve Cemal Paşalar, Azmi Bey, Emmanuel Karasu, Nesim Roso gibi kişilerin de öldürülmesinin planlandığı fakat gerçekleştirilemediği daha sonra polis raporlarından ve tanık ifadelerinden anlaşılmıştır. Ancak siyasi açıdan özellikle 1918'de iktidarın el değiştirmesi ile birlikte Vahideddin ve onu destekleyenler özellikle de Mahmut Şevket Paşa suikastı sonucunda İstanbul'u terk etmek zorunda kalan ve cezalandırılan Hürriyet ve İtilafçılar, yaşadıkları sıkıntıları unutmayarak, İttihatçılara karşı sert bir politika uygulamışlardır.

Mahmut Şevket Paşa suikastı, daha önce yapılan çalışmalarda gazeteler temel alınarak araştırılmıştır. Bu çalışmayla, arşiv belgeleri esas alınarak Mahmut Şevket Paşa suikastının neden, ne zaman, nerede, nasıl gerçekleştiğini tespit etmek ve sonuçlarını değerlendirmek amaçlanmıştır.

Anahtar kelimeler: Suikast, İttihat ve Terakki, Hürriyet ve İtilâf, Mahmut Şevket Paşa, Beyanname

\section{Abstract}

Mahmut Şevket Pasha is the Ottoman Grand Vizier and the Minister of Military Affairs. Throughout history, he has been subjected to many criticisms from both military and political aspects. In terms of military aspect, his harsh stance during the Albanian revolts, the decisions he took during the Tripoli and Balkan Wars, and politically his relations with the Committee of Union and Progress were discussed. He also has a dominant personality over the parliament and the members of the parliament. He was perceived as a Unionist due to his close attitude to the Committee of Union and Progress and was assassinated on June 11th, 1913 while he was driving from to the Ministry of Military Affairs his post at Babiali and died after a while.

The assassination of Mahmut Şevket Pasha was considered as a political opportunity for the Party of Union and Progress. They punished some of their rivals by associating them with this assassination and removed them from Istanbul. Many people from different backgrounds and views participated in the assassination which can also be described as the first planned assassination attempt in terms Ottoman Grand Vizier and the military minister of Ottoman history. In addition to many political and military people, it is understood that there were also those who supported this assassination for personal or family reasons as well as those whose requests were not realized during the period of the Union and Progress government. Important figures such as Prince Sabahattin, Şerif Pasha and Damat Salih Pasha cooperated financially with the assassins. The assassins also asked them to disembark their soldiers from the ships in Istanbul and intervene in the incident with the declarations sent to the other embassies in Austraia, one of the great states of the period, and Istanbul on the day of the assassination. This assassination can also be considered as a move against the Babiali raid by the Unionists. Many members of the Freedom and Alliance Party, which opposed the Unionists, also supported the assassination. The execution of Damat Salih Pasha as a result of this assassination caused reactions in the family of the dynasty. Regardless of what happened, the Unionists showed their harsh attitude demonstrating that they will not make concessions to such attempts against them. Many people associated with the assassination were sentenced to death, punished by crowd, or exiled. 
The assassination of Mahmut Şevket Pasha occupies an important place in our political history in terms of its results. In fact, it is understood from police reports and witness statements that not only Mahmut Şevket Pasha but also people such as Talat and Cemal Pashas, Azmi Bey, Emmanuel Karasu and Nesim Boso were planned to be killed. However, politically, with the change of power in 1918, Vahdeddin and his supporters, especially Freedom and Alliancists, who were forced to leave Istanbul and punished as a result of the assassination of Mahmut Şevket Pasha, did not forget their troubles and implemented a harsh policy against the Unionists. The assassination of Mahmut Şevket Pasha was previously investigated on the basis of newspapers. The aim of the study is to determine why, when, where and how the assassination of Mahmut Şevket Pasha took place in the light of documents and to evaluate the results.

Keywords: Assassination, Committee Of Union And Progress, Freedom And Alliance, Mahmut Şevket Pasha, Decleration

\section{GİRIŞ}

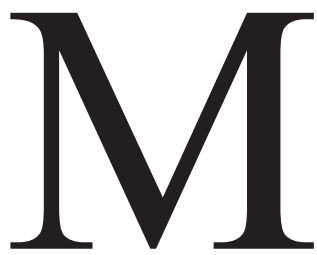

ahmut Şevket Paşa, Osmanlı Devleti'nde Harbiye Nazırlığı ve sadrazamlık görevlerinde bulunmuştur. Kendisi askeri tarihte olduğu kadar siyaset tarihinde de tartışmalara konu olmuş bir kişidir. Özellikle Trablusgarp ve Balkan Savaşları sırasındaki icraatları askeri tarihte, İttihat ve Terakki Cemiyeti ile yakınlığı ve daha sonra bu cemiyet ile arasının açılması da siyasi tarihte eleştirilere ve tartışmalara konu olmuştur. Onun hayatı kadar ölüm şekli de Osmanlı Tarihi açısından önemlidir. Bilindiği üzere, 11 Haziran 1913 tarihinde bir suikasta kurban gitmiştir. Osmanlı Tarihi açısından, Osmanlı Sadrazamı ve Harbiye Nazırı bir kişinin böyle planlı bir suikast sonucu öldürülmesi önemlidir. Aynı zamanda bu suikast, siyasete konu edilmiştir. Konu Mahmut Şevket Paşa- İttihat ve Terakki ilişkileri açısından değerlendirildiğinde, İttihat ve Terakki mensuplarının bu suikastı bahane ederek rakiplerini ortadan kaldırmak için durumu bir fırsat olarak kullandıkları görülmektedir.

Esas olarak konu değerlendirildiğinde İttihat ve Terakki yönetiminden umduğunu bulamayan ya da onun içerisinde yer alamayan pek çok kişinin bu suikasta katıldığ görülmektedir. Bu suikast bir hükümet darbesi niteliği taşımakta olup, sadece Mahmut Şevket Paşa'yı değil Talat ve Cemal Paşalar, Emmanuel Karasu, Nesim Roso gibi İttihatçıların önde gelen pek çok isimlerini de hedef almıştır. Ayrıca bu şekli ile genel bir ihtilâl ortaya çıkarma girişimi olarak da nitelendirilebilir.

Mahmut Şevket Paşa suikastı sırasında Cemal Paşa İstanbul Muhafizlığı, Azmi Bey ise Polis Umum-u Müdürü görevinde bulunmaktaydı. Daha önceki çalışmalarda konu daha ziyade gazeteler esas alınarak incelenmiştir. Osmanlı arşiv belgelerinde bu suikastın yeri ise pek de araştırılmamıştır. Çalışma, bu nedenle Osmanlı vesikaları esas alınarak özellikle polis tahkikat raporları çerçevesinde Mahmut Şevket Paşa suikastının ortaya konmasını amaçlamaktadır. Çalışmanın problematiğini bu suikastın kimler tarafından, ne zaman, niçin, nerede, nasıl meydana geldiğini açıklamaya çalışmak teşkil etmektedir. 


\section{1-MAHMUT ŞEVKET PAŞA’NIN SADARETE GETIRILISŞI}

Mahmut Şevket Paşa'nın siyaset sahnesine çıkışı, II. Meşrutiyet'in ilanı ile İstanbul'dan Meşrutiyet' in korunması için 3. Ordu' dan Avcı Taburları istenmesi üzerine olmuştu. ${ }^{1}$ Assıl tanınması 31 Mart Vakası sırasında Hareket Ordusu'nun başında İstanbul'a gelmesiyle olmuştu. Bu dönemde Osmanlı Ordusu'nun karmaşık bir yapıya sahip olduğu görülmekteydi. Bu durum II. Abdülhamit ve Jöntürkler döneminde de devam etti. Ordu içerisinde askeri okullarda yetişen ve rütbe alarak yükselenlerle, devletin geleneksel kurumlarına tam bir bağlılık içinde olanlar yani alaylılar arasında keskin bir mektepli-alaylı ayrımı söz konusuydu. Ayrıca eski paşalarla genç subaylar arasında da kuşağa dayalı bir ayrım vardı. 31 Mart hadisesi sırasında oluşturulan Hareket Ordusu da karmaşık güdülere sahip olarak İstanbul'a doğru yola çıkmıştı. Enver, Mustafa Kemal ve Fethi Beyler gibi o dönemde alt kademede bulunan subaylar, anayasayı ve İttihat Terakki Cemiyeti'ni desteklerken öne çıkan üst kademedeki subaylar farklı yönelimler peşindeydi.

Mahmut Şevket Paşa'nın Hareket Ordusu ile İstanbul'a gelmesi ve sonrasında İttihatçıların devlet idaresindeki otoritelerini güçlendirmeleri ile Paşa'nın İttihatçı olduğu yönünde suçlamalarda bulunulmuştur. İstanbul'da İngiliz Konsolos Vekili Lamb, Hareket Ordusu Kumandanı Mahmut Şevket Paşa için İttihat ve Terakki Cemiyeti'nin asla kumandası altında olmadığını ifade etmiştir. Orduda bozulan disiplinini yeniden sağlanmak için ordu namına ve tehdit altındaki anayasal özgürlüklerin korunması için millet adına çalıştığını da belirtmiştir. ${ }^{2}$ Mahmut Şevket Paşaİttihat ve Terakki ilişkileri açısından bu tespit önemlidir. Yani Mahmut Şevket Paşa, İttihatçı olduğu için değil kendi yetiştirilmesi ve terbiyesi gereği zaman zaman İttihatçılarla aynı şekilde hareket etmiştir. Buna rağmen pek çok konuda da İttihatçılarla anlaşmazlıklar yaşamıştır. Paşa bu durumu günlüğünde yazdığı 'ben müstakil fikirli bir adamım. İttihat ve Terakki'nin oyuncağ1 olamam. İttihat ve Terakki Umumi Merkezi sathi fikirli adamlardan mürekkeptir. Balkan Harbi çıkmadan Yunanistan'la ittifak ederek bu devleti diğer Balkan Devletleri'nden ayıralım dedim, kimse kulak asmadı. Trablusgarp Harbi'ni uzatmayalım, Balkan Devletleri'nin ittifakına zemin

1 Abdülmecid döneminde, Basra Mutasarrıfı Çeçen asıllı Kethüdazade Süleyman Bey’in oğlu olan Mahmut Şevket Paşa 1856 doğumluydu. Bağdat'ta bulunan Rüşdiye' de okudu ve sonra askeri okula devam etmek için İstanbul'a gitti. Üsküdar Atlamataşı Askerî Rüşdiyesi ve daha sonra Kuleli Askerî İdadisi'ne devam etti. 1876'da girdiği Mekteb-i Harbiye'den 1878'de mezun oldu ve Erkân-1 Harbiye sınıfına geçti. Ailesinin uzun süre Bağdat’ta yaşamasından dolayı "Arap" olarak da adlandırıldı. Harbiye Mektebi’nde "Arap Mahmud" lakabıyla tanınmıştı. 1880'de yüzbaşı olarak rütbe aldı. Erkân-1 Harbiye İkinci Şubesi'nin telif ve tercüme bürosunda göreve başladı. İyi derecede Arapça, Almanca ve Fransızca bilmekteydi. Mekteb-i Harbiye'de cebir, hendese, fenn-i esliha, endaht nazariyesi gibi dersleri verdi. Birçok dergide yazılar yazdı ve tercümeler yaptı. Von Der Goltz Paşa'nın muavini olarak Mekteb-i Harbiye’yi islah çalışmalarına da katıldı. 1884'de kolağası, 1886'da binbaşı oldu. Osmanlı Devleti'nin Almanlardan yeni silahlar alınması hususunda kurduğu ve yetkilendirdiği komisyonda görev aldı. 1890'da miralay oldu. Fransa ve Almanya'ya incelemelerde bulunmak için gitti. Osmanlı Devleti'nin Almanlardan alacağ silahların seçiminde rol oynadı. Uzun yıllar Almanya'da kaldı. 1895'de Mirlivâ, 1901'de ferik oldu. Bu sırada Mekke-Medine arasındaki telgraf hattının yapılmasına memur edildi. Kendine verilen bu görevi bir sürgün olarak algıladı ve II. Abdülhamit'e cephe aldı. Kısa süre sonra eski vazifesi başına döndü. 1905 'te birinci ferik olarak rütbesi yükseltildi ve Kosova Valiliği’ne tayin edildi. Burada İttihat ve Terakki Cemiyeti ile ilişkiler kurdu ve bunların rejim aleyhtarı hareketlerine sessiz kaldı. 1908'de 3. Ordu Kumandanlı̆̆ı'na tayin edildi. Daha detaylı bilgi için bkz: İbnülemin Mahmut Kemal, Son Sadrazamlar, C.IV, Dergah Yayınları, İstanbul 1982, 3. Bask1, s. 1869-1881, Zekeriya Türkmen, "Mahmud Şevket Paşa (1856-1913)" Türkiye Diyanet Vakfi İslam Ansiklopedisi, C. 27, Ankara 2003, s. 384-386

2 Sina Akşin, Sarp Balc1, Barış Ünlü, 100. yılında Jön Türk Devrimi, İş Bankası Kültür Yayınları, İstanbul 2010, s. 27 
hazırlar, Rumeli'yi kaybedebiliriz dedim, Babıali beni dinlemedi. O zaman fikirlerimi şiddetle ileri sürmediğim için şimdi vicdan azabı içindeyim. Artık herhangi bir zaif eseri göstermeyeceğim" sözleri ile açıkça anlatmaktadır. ${ }^{3}$ Bu sözlerle kendisini İttihatçılardan ayırmış, hatta bazı konularda İttihatçılarla arasında anlaşmazlık noktaları olduğunu da açıkça dile getirmiştir.

İstanbul'a gelen Hareket Ordusu Kumandanı Mahmut Şevket Paşa, şehri kısa sürede işgal etmiş, sıkıyönetim ilan ederek, Sultan Reşat'ın tahta çıkmasında etkin rol oynamıştı. Paşa daha sonra 18 Mayıs 1909'da Birinci, İkinci, Üçüncü Ordular müfettişliğine getirildi. Sert mizacı sayesinde hükümet ve meclis üzerinde kısa zamanda otoritesini kurdu. Özellikle Mebusan Meclisi'ndeki Suriye ve Irak Mebusları, kendi menfaatleri doğrultusunda kuvvetli gördükleri Hareket Ordusu Kumandanı'nı benimseyerek onun etrafında toplanmışlardı. Mahmut Şevket Paşa'nın icra ettiği gizli nüfuz sayesinde işlerini kolaylaştırmak ve konumlarını korumak istemişlerdi. Bu durum İttihat ve Terakki Cemiyeti'nin sivil azaları ile Mahmut Şevket Paşa'nın şahsında ortaya çıkan askeri diktatörlük arasındaki zıddiyetin gizli gizli çarpışmasına neden olmuştu. ${ }^{4} \mathrm{Bu}$ vesile ile bu dönemde çok tartışılan konularından biri de askerin siyasetten el çektirilmesi oldu.

Mahmut Şevket Paşa, Hüseyin Hilmi Paşa'nın sadareti döneminde baskın bir rol oynamış, İbrahim Hakkı Paşa Kabinesi'nde ise Harbiye Nazırlığı'na yükseldi. Buna rağmen üzerinde bulunan her üç ordunun müfettişliği görevini de bırakmadı. Mahmut Şevket Paşa'nın siyasi alanda etkili bir isim olması kısa süre sonra İttihatçıları rahatsız etmeye başladı. Paşa'nın Arnavut İsyanı'ndaki sert tavrı, Balkan Savaşları'ndaki çözülmenin ve bölgeden Yemen İsyanları'nı bastırmak için asker çekmesi de İtalyanların Trablusgarp'a saldırmaları sırasındaki zayıf direnişin nedenleri olarak algılandı. Bu durum eleştirilere hedef oldu. ${ }^{5}$ Said Paşa Kabinesi'nde de Harbiye Nazırlı̆̆ 1 görevini korudu ise de ancak Temmuz 1912'de istifa etmek zorunda kald1. Gazi Ahmet Muhtar Paşa Kabinesi'nde Balkan Savaşları sırasında Alasonya Ordusu Kumandanlığı'na getirildi. Bu görevin başarıya ulaşamayacağını öngörerek istifa etti. Buna rağmen yenilgi sonucunda basın ve muhalefetin olumsuz eleştirilerinden kurtulamad1 ${ }^{6}{ }^{K}$ Kendisine bu görevden neden istifa ettiği sorulduğunda "bu benim şöhretimi ve şeref-i askerîmi ihlâl etmek için yapılmıştı. Şerefimi nasıl feda ederim?" diyerek yanıt vermişti. ${ }^{7}$

Balkan Savaşları'nda, Bulgarların Edirne'yi de alarak İstanbul önlerine kadar gelmeleri, bir barış anlaşması zorunluluğunu doğurdu. Bu sırada Bulgaristan'ın Romanya ile birlikte, komşularıyla savaşmak zorunda kalması, Trakya ve Edirne'nin yeniden alınabilmesi için bir firsat olarak görüldü. Ancak Kamil Paşa Kabinesi Edirne’yi gözden çıkararak, Midye-Enez hattını sınır çizgisi olarak kabul etmeye hazır olduklarını dile getirmişlerdi. Bu durumu engellemek için Talat ve Enver Paşalar'ın girişimleri ile Babıali Baskını düzenlendi ve baskın sırasında Harbiye Nazırı Nazım Paşa öldü. Kamil Paşa istifa etmek zorunda kaldı. Böylece 23 Ocak 1913'te kurulan yeni kabineye İttihatçıların teklifi ile Mahmut Şevket Paşa Sadrazam olarak getirildi. ${ }^{8}$

3 Sadrazam ve Harbiye Nazırı Mahmut Şevket Paşa’nın Günlüğü, Arba Yayınları, İstanbul 1988, s.27

4 Hüseyin Cahit Yalçın, “Meşrutiyet Hatırları (1908-1918)”, Fikir Hareketleri, İstanbul 1933, S. 118, s. 212

5 Türkmen, agm, s. 384-386

6 Türkmen, agm, s. 384-386

7 Ali Fuad Türkgeldi, Görüp İşittiklerim, Türk Tarih Kurumu Yayınları, Ankara, 2010, 5. Bask1 s. 64

8 Lütfi Simavi, Osmanlı Sarayının Son Günleri, İstanbul 1979, s.330-331 
Mahmut Şevket Paşa, hükümetin kuruluşunu resmi suretle tamamladığında ilk iş olarak eski kabine üyelerinin durumunu ele almıştı. Bunlar Babıali' de muhafaza altında bulunduruluyorlardı. Paşa, eski nazırlara selam ve hürmetlerini gönderirken bir arzuları olup olmadığını da sordu. Kamil Paşa ve Cemalettin Efendi’ye karşı ise daha dikkatli davranmıştı. Bunlara "bu hadisenin mukadderatı İlâhiye'nin bir cilvesi olduğunu kabul buyurmaları” mesajını göndermişti. Kamil Paşa ise bu durum karşısında, bir an evvel evlerine dönmek istediklerini belirterek "Gelişleri bize benzemedi, gidişleri de bize benzemesin." diyerek anlamlı ve imalı bir temennide bulunmuştu. ${ }^{9}$

Sultan Mehmet Reşat saltanatı döneminde Mahmut Şevket Paşa'dan çekinmiştir. Sultanın Başmabeyncisi Ali Fuad Türkgeldi bu durumu 'Paşa'nın çehresinin korkunçluğu ile beraber sert ve sür'atli adımlarla sofadan geçerek ve ayağındaki mahmuzlu çizmelerle parkeleri çatırdatarak huzura gelişinden adeta ürperirdi." diyerek anlatır. Sultanın, hem Harbiye Nazırlığı hem de Sadrazamlık görevini üstlenen Mahmut Şevket Paşa için "Bari sadaretten çekilse de Harbiye Nezareti'nde kalsa." diyerek Paşa'nın iki görevi birlikte sürdürmesinden rahatsız olduğunu ancak bunu Paşa'ya söyleme cesaretinin olmadığını da belirmiştir. Ayrıca konuşmalarında sık sık "Harbiye Nazırı Paşa devletin bir ordusudur." diyerek onun gücüne işaret etmiştir. Tüm bunlara rağmen Paşa her iki görevine de devam etmiştir. Sadrazamlığındaki pürüzlü meseleleri temizleme emeli, uğradığı suikast ile sonlanmıştır. ${ }^{10}$

\section{2- MAHMUT ŞEVKET PAŞA SUIKASTI}

İttihatçılar, Babıali Baskını ile muhaliflerini bir derece sindirmişti. Fakat bu uzun sürmedi. Baskından bir ay kadar kısa bir zaman sonra bir taklib-i hükümet yani hükümeti devirme girişimi olacağına dair haberler alınmaya başlandı. ${ }^{11}$ Buna göre Prens Sabahattin, Babıali Baskını'nın halk üzerindeki heyecanından istifade ederek İttihatçılar aleyhinde bir hareket ortaya çıkarmak istiyordu. ${ }^{12}$ Bunun için de halkın hissiyatını kullanacaktı. İttihatçılar Edirne’yi geri alacaklarını vadetmişlerdi. Fakat ordu uzun süredir Çatalca önlerinde bekliyordu. Edirne düşünce Bulgarlar Gelibolu’yu işgal edecek işte bu sırada büyük bir kalabalık Babıali’ye yürüyerek bir ihtilâl meydana getirilecekti. Hükümetin görevden çekilmesi sağlanacaktı. Aynı kalabalık saraya giderek padişahtan hükümetin istifasını kabul etmesini isteyecek ve sadrazamın Divan-1 Alî’ye sevk edilmesi sağlanacaktı. İttihat ve Terakki erkânı hapsedilerek bir vapura bindirilip sürgüne gönderilecekti. Böylece adem-i merkeziyetçi bir hükümet kurulacaktı. ${ }^{13}$

Bu planı yapan Prens Sabahattin ve grubu, diğerlerinden farklı olarak kanlı bir hareketten yana değildi. Daha ziyade miting ve bildiri yoluyla İttihatçı kabineyi devirmek istiyorlardı. Bu nedenle

9 Celal Bayar, Bende yazdım Milli Mücadele’ye Gidiş C.IV, Sabah Yayınları, İstanbul 1997, s. 36-37

10 Türkgeldi, age, s.99- 102

11 Cemal Paşa, age, s.20

12 Prens Sabahattin Bey, Osmanlı Devleti yönetiminde kendisine yer edinmek istiyordu. Bunun için de etrafına bazı kişileri toplamıştı. Hedefine ulaşabilmek için yabancı komitacılar ile anlaşmıştı. Kısa zamanda "Teşebbüsü Şahsi Adem-i Merkeziyet" adlı bir cemiyet kurdu. Önceleri İttihat ve Terakki bu cemiyetle birleşmek istemişse de Prens bunu kabul etmemişti. Yabancı unsurlardan kuvvet almaya çalışan Prens Sabahattin Bey ile İttihatçıların arası zamanla açıldı. Daha detaylı bilgi için bkz: Ziya Şakir, Mahmut Şevket Paşa, Akıl Fikir Yayınları, İstanbul 2011, s.209-211

13 Tarık Zafer Tunaya, Türkiye'de Siyasal Partiler Cilt. 3 İttihat ve Terakki Bir Çağın Bir Kuşağın Bir Partinin Tarihi, İstanbul 2000, 2 bask1, s.517 
prensin adamlarından Satvet Lütfi riyasetinde "Osmanlı Milleti ve Ordusu'na hitaben" başliklı bir bildiri Beyoğlu'nda Tünel Meydanı'nda Yunan asıllı Pantazi’nin “Anadolu” adlı matbaasında bastırıldı. Pantazi bu bildirilerden bir kısmını evine götürmüş, bir kısmı da matbaada bırakmıştı. Erzurumlu Serdar Sıktı adlı bir kişinin Satvet Lütfi riyasetinde bu matbaada bu bildirileri basmaya çalıştığı sırada takibata uğraması sonucu olay açığa çıkmıştı. Bu kişi tutuklandı ve ifadesi alındı. Polisin takibi sonunda bildirilerden bir kısmını evine götüren jandarma mülâzımlığından emekli Mustafa Vasfi Efendi bildirilerle evinde basıldı. Ayrıca bundan sonra da olayla ilgili kişilerin tutuklanmaları devam etti. Satvet Lütfü, Avusturya Sefareti tercümanlarından Mösyö Lazare'nin apartmanında yakalandı. Fakat kapitülasyonlar nedeniyle Cemal Paşa sefarethaneye giderek açıklama yapmak zorunda kald1. ${ }^{14}$

Suikasttan kısa zaman önce Ahmet Bedevi de tutuklanmıştı. Bu durum İttihatçıların istihbaratlarının ve komitacılık işlerinde tecrübelerinin ne kadar kuvvetli olduğunu göstermesi açısından önem arz ediyordu. Cemiyet suikastçılarla işbirliği yapan Yüzbaşı Şair Celis’i kullanarak da istihbarat almıştı. Nitekim bu tutuklamalar suikastla ilgili kimselerin yakalanması açısından isabetliydi. Prens Sabahattin kendi adamlarının tutuklanmalarından sonra ihtilâl ya da suikast planlarında daha geri durmuştu. Ahmet Bedevi'nin bu suikast planlamasında muhtelif teşekküller arasında irtibat vazifesi gördüğü anlaşılmıştı. Kuruçeşme'den aldığı izlenimleri Gümülcineli İsmail Bey Cephesi'ne fikren takviye etmeye çalışırken diğer gruplardan da haberdar olmaya çalışmıştı. Erkan-1 Harp Kemal, Yüzbaşı Kudret Beylerle, Kemal Paşa gibi bazı zabitler arasında da irtibat kurmuştu. Yüzbaşı Çerkez Kazım ve Nazmi Beyler en tehlikeli rolleri ifaya hazır ve mutlaka kan dökülmesine taraftardı. Sabahattin Bey'e yaptıkları müracaatlara ret cevabı alınca başka taraflara yönelmişlerdi. Kuvvete dayanmayan bir siyasi hareketin manasızlığını idrak etmişlerdi. Bazı İttihat ve Terakki ileri gelenlerinin ortadan kaldırılmaları lüzumunu 1srarla müdafaa ediyorlardı. ${ }^{15}$ Damat Salih Paşa ise bu suikast istihbaratının alındığı günlerde suikastçılarla ilişkisi anlaşılmıştı. Cemal Paşa tarafından bu tür kişilerle ilişkisini kesmesi konusunda birçok kez uyarılmış, ancak bu uyarılara kulak asmamıştı. ${ }^{16}$

Cemal Paşa'nın Damat Salih Paşa ile konuşmasından birkaç gün sonra Kamil Paşa da İstanbul'a gelmişti. Bu duruma Cemal Paşa "hah! bir bu eksikti. Şimdi tamam oldu. Şu halde bu cüretkâr herifler, kazanacakları muvaffakiyetten o kadar eminler ki, sadrazamı bile getirdiler diye tepki ile karşılamıştı. ${ }^{17}$ Görüleceği üzere sadrazam olarak düşünülen Prens Sabahattin'in, adamlarının tutuklanması nedeniyle kendini olaylardan uzak tutması, Kamil Paşa'nın sadrazamlığının suikastçılar tarafından desteklenmesine sebebiyet vermiştir.

Bir ihtilâl ve suikast girişimi yapılacağı bilindiği halde buna engel olunamadı. Mahmut Şevket Paşa Babıali Baskını'ndan sonra işbaşına geldiğinin dördüncü ayında bir taraftan devam eden Balkan Harbi ile diğer taraftan memleketin sorunları ile uğraşırken üzerinde bulunan sadrazamlık ve Harbiye Nazırlığı görevinden dolayı Harbiye Nezareti ile Babıali arasında her gün muhtelif saatlerde gidip gelmekteydi. 11 Haziran 1913 Çarşamba günü sabahı da yanında seryaveri Eşref, yaveri Mülâzım İbrahim Bey ve uşağı Kazım Ağa olduğu halde Harbiye Nezareti’nden çıkmış Babıali’ye

14 Tunaya, age, s.517, Cemal Paşa, age, s.20-21, Ziya Şakir, age, 223

15 Ahmet Bedevi Kuran, İnkılap Tarihimiz ve Jön Türkler, Tan Matbaası, İstanbul,1945, s. 232- 323

16 Cemal Paşa, Hatırat, Arma Yayınları, İstanbul 1997, 4. Baskı, s. 25-30

17 Ziya Şakir, , age, s. 264 
gitmek üzere otomobil ile yola koyulmuştu. Beyazit Meydanı'nı geçip Çarşıkapı'ya dönecek olan otomobil tam bu sırada Gedikpaşalı Saraylı Hanım'ın cenaze alayının ortaya çıkması ile durmak zorunda kalmıştı. Tamir çalışmalarının devam etmesi nedeni ile yol iyice daralmıştı. İşte tam bu esnada daha önce Tramvay Caddesi'nin arka tarafına konuşlanmış olan bir otomobilden çıkan üç şahıs Osmanlı Sadrazamı'nın otomobiline ateş açmak suretiyle suikastı gerçekleştirmiş̧ti. ${ }^{18}$ Refik Halit Karay anılarında memleketimizde ilk makam otomobiline Harbiye Nazırı Mahmut Şevket Paşa'nın bindiğini ve onun otomobili içinde öldürüldüğünü söyleyerek "eskiden suikastlar arabada olurdu; Mesela Fransa Cumhur Reislerinden Carnot'u bir anarşist makam landosuna siçrayarak kama ile vurmuştu. Portekiz Kralı ile veliahdını otomobilde öldürmüşlerdi. Yugoslav Kralı ve Fransız Hariciye Nazırı Bartoux da yan yana otomobil içinde vuruldular. Birinci Cihan Harbi'nin patlamasına sebep olan Saraybosna Suikastı da otomobil mi, araba mı? Herhalde tekerlekli bir nakil vasıtası içinde yapılmıştır" diyerek bir kıyaslama da yapmışt. ${ }^{19}$ Mahmut Şevket Paşa'da döneminde diğer önemli devlet adamlarınınkine benzer bir şekilde otomobili içinde kurşunlara hedef olmuştu.

Katiller sağdan soldan attıkları tabanca kurşunlarını otomobile yağdırmışlardı. Bu sırada yaverlerinden İbrahim Bey kanlar içinde Paşa'nın ayakları altına yığılmış, diğeri de otomobilden atlayarak "Paşa' yı vuruyorlar polis inzibat yok mu?" diye bağırmaya başlamıştı. Katiller otomobiline binerek olay mahallinden kaçmışlardı. Paşa'nın resmi üniforması hâlâ üzerinde olduğu halde ağır bir şekilde yaralanmıştı. Paşanın şoförü bu sırada otomobili Harbiye Nezareti'ne doğru döndürmüştü. Paşa'ya 5 kurşun isabet etmiş, bir tanesi kafasının sağ yanını delerek gözünü çıkarmış ve beynine dayanmıştı. Bu sırada henüz ölmemiş olduğu ve "millet hainleri, hürriyet katilleri" gibi sözler sarf ettiği duyulmuştu. Ancak yapılan müdahalelere rağmen kısa süre sonra da hayatını kaybetmiştir. ${ }^{20}$

Silah seslerinin ardından orada bulunan Polis memuru İsmail Hakkı Efendi bir şahsın tramvay caddesinden Gedikpaşa'ya doğru kaçtığını görmüş ve peşine düşmüştü. Polise karşı silah açan şahsın düşmesi üzerine polis onu vurduğunu sanmış, ancak toparlanarak tekrar kaçmaya başladığını fark etmiş̧i. Bir ara şahsı polis kaybetmişse de jandarmaların aracılığ ile takip devam etmişti. Gedikpaşa Hanı'nın abdesthanesinde şahsın attığı şarjörler ve fişekler ele geçirilmiş, abdesthane civarındaki gusülhanede de dördü atılmış ve biri atıldığı halde patlamamış beş kurşunlu bir revolver ile bir bıçak bulunmuştu. Ele geçirilen bu şahsın Küçükpazarlı işsiz, hayırsız Küçükmustafapaşalı Topal Tevfik olduğu anlaşılmıştı. ${ }^{21}$ Başlatılan tahkikatta Kamile Hanım adlı bir kadının ve gönüllü asker olup terhis edilen Nuri Efendi'nin, Topal Tevfik'i sadrazam paşaya silah atarken gördüğü yolunda ifade vermesi üzerine şahıs teşhis edilmişti.

Paşaya düzenlenen suikastın failleri arasında bulunan, otomobil içerisindeki diğer şahıslar ise Aksaray-Şehremini yoluyla Topkapı'dan dışarı çıkarak Eyüp istikametine yönelmişlerdi. Silahdarağa yolu üzerindeki handan su almak için duran otomobilin şoförünün, ihtiyacı karşılamak üzere otomobilin su deposunun kapağını açtığı sırada ortaya çıan buharın şiddetinden dolayı yüzü yanmıştı. Çerkez Abdurrahman'ın idaresinde hareket eden ve onun arkadaşlarından Cevad ve Ziya olduğu anlaşılan bu kişilerden, Abdurrahman'ın arkadaşı Cevad'la birlikte kaçmayı başarmıştı.

18 Başbakanlık Osmanlı Arşivi (BOA), Dahiliye Nezâreti Siyasî Kısım Belgeleri (DH.SYS).119/1-6.6,1

19 Refik Halit Karay, Bir Ömür Boyunca, Türk Tarih Kurumu, Ankara 2011, s. 247-248

20 Samih Nafiz Tansu, İttihat ve Terakki İçinde Dönenler ( Anlatan: Galip Vardar ), Yeni Zamanlar Yayınları, İstanbul 2003 s. 229 -231

21 BOA, DH.SYS. 119/1-6.6,1 
Bunun üzerine Abdurrahman'ın babası Hacı Nazmi'nin evinde arama yapılmış, orada bulunan Cevad ile onu saklayan Nazmi Bey de tutuklanmıştı. Her ne kadar yapılan sorgulamada Cevad suçunu inkâr etmişse de yüzünün yandığını görenler tarafından otomobilde olduğu teşhis edilmişti. Daha sonra Cevad'ın itirafı ile olay aydınlatılmıştı. Bunlardan başka kumar ve işrethane işlerinde bu şahıslarla beraber hareket eden Kumarhaneci Kör Emin, Çerkez Nazmi, Nazmi'nin biraderi Nuri, Kenan ve Polis Kısm-1 Siyasi Müdür-i sabıkı Muhib de tutukland1. Ancak tutuklananlar arasında önemli bir isim daha vardı ki bu Damat Salih Paşa idi. ${ }^{22}$ Suikastın meydana geldiği bölge polis müdüriyetince bir kroki çizilerek de gösterilmişti. (Ek 2) $)^{23}$

\section{3- POLİS TAHKIKAT RAPORLARINDA MAHMUT ŞEVKET PAŞA SUIKASTI}

Mahmut Şevket Paşa gibi Sadrazamlığı ve Harbiye Nazırlığı görevlerini uhdesinde bulunduran otoriter bir devlet adamının planlı ve ani bir suikasta kurban gitmesi, kamuoyunda şok etkisi yaratmıştı. Polis Umumi Müdürü Azmi Bey tarafından Dâhiliye Nazırı'na gönderilen 20 Haziran 1913 tarihli rapora göre (Ek 1):

Memlekette bir ihtilâl ve kıyam gerçekleştirmek için böyle bir suikast yapıldı̆̆ı, bu suikast sırasında Mahmut Şevket Paşa ve yaveri İbrahim Bey’in katledildiği anlaşılmaktaydı. Ayrıca bu suikastın sadece Mahmut Şevket Paşa'ya yönelik olmadığı, Polis Müdür-i Umumisi Azmi Bey, Talat Paşa, Cemal Paşa ile Nesim Roso ve Emmanuel Karasu'nun da hedef alındığı anlaşılmıştı. Katillerin Beyoğlu'nda Pire Mehmet Sokağı'nda bir hanede saklandıkları tespit edilmişti. Bu eve yapılan baskında askere ateş açılmıştı. Yüzbaşı Hilmi Efendi'nin katledilmesi, Samuel Efendi'nin de yaralanması sonucunda nihayet buradaki kişiler cinayete iştirak suçuyla tutuklanabilmişti.

Prens Sabahattin Bey tarafindan, bu suikastın bir süreden beri İstanbul'dan sevk ve idare edildiği ve özellikle mali olarak desteklendiği, onun hususi kâtibi Satvet Lütfi ve arkadaşlarının ifadelerinden anlaşılmıştı. Prens Sabahattin Bey adamlarının tutuklanması sonucu pasif konuma çekilmişti. Ancak onun tarafından mühim bir para ile Doktor Nihat Bey’in Atina'ya gönderildiği ve burada bulunan esir zabitan üzerinde hükümete karşı propaganda yapmakla görevlendirildiği de öğrenilmişti. Prens Sabahattin'in başlattığı bu hareket, polis raporlarında "çete" olarak nitelendirilmişti. Prens 1.700 lira parayı bu iş için vermişti. Bu paraları suikast için harcama yetkisi Ahmet Bedevi’ye verilmişti. Prensin çabalarıyla Dr. Nihat Bey Avrupa'ya gitmiş, ancak Satvet Lütfi ve Ahmet Bedevi'nin tutuklanmalarına engel olunamamıştı. Bu tutuklamalar üzerine Kazım, Muhib ve Nazmi Beyler, Prens Sabahattin ile temaslarda bulunan kişiler arasında yer almışlardı. Pertev Tevfik'in riyasetinde Glavani Sokağı'ndaki Müdafaa-i Milliye Cemiyeti Gazetesi İdarehanesi'nin bulunduğu apartmanda ara sıra toplantılar düzenlenmişti. Bu toplantılara Gümülcineli İsmail Bey’in yanı sıra Muhib, Kazım, Ziya, Hakkı, Nazmi, Topal Tevfik ve Kara Ahmet gibi kişiler de iştirak etmişlerdi. ${ }^{24}$

Kazım, Prens Sabahattin ile temas kurmuş ve kendisinden suikastlar için 1.500 lira para talep etmişti. 1.000 liranın bankaya yatırılması, 500 liranın da kullanılmak üzere elden verilmesini istemişti. Ancak istekleri boşa gitmişti. Çünkü Prens Sabahattin'in adamlarının tutuklanmasından

\footnotetext{
22 BOA, DH: SYS 119/1.6.6,2

23 BOA, DH. SYS 119/1.6.7

24 BOA, Dahiliye Nezâreti Kalem-i Mahsus Müdüriyeti Belgeleri (DH.KMS). 63/63-2
} 
sonra geriye çekilmek zorunda kalmıştı. Kazım ise ihtilâl işinde bundan sonra daha etkin bir rol oynamış ve bu ihtilâli yapmakta çok kararlı davranmıştı. Kazım, Prens Sabahattin'den bulamadığı maddi desteği Damat Salih Paşa'da aramış ve onunla çalışmaya başlamıştı. Muhib Bey vasıtasıyla Damat Salih Paşa ile irtibat kurulmuştu. Salih Paşa bu paranın sağlanmasına aracılık etmişti. Böylece Köstence'de bulunan Romanya Bankası'ndan 10.000 Frank almak için Muhib ve Kazım Beyler Romanya'ya gitmişti. Burada Reşit Bey ile de irtibat sağlamışlar ve ihtilâl için gerekli parayı tedarik etmişlerdi. Suikastların planlanması işi Galatasaray Hamamı yakınlarındaki bir hanede gerçekleşmişti. Muhib ile Komiser Latif Efendi burada bir araya gelerek bu teşebbüs hakkında planlamalara başlamışlardı. Kazım Bey kırmızı benekli bezleri parola olarak belirlemiş ve suikastı gerçekleştirecek üyelere dağıtmıştı. Muhib Bey'in bu sırada yakalanmasına rağmen Kazım Bey marifetiyle işe devam edilmiş ve durum fikirden fiile geçirilmişti. ${ }^{25}$

Kazım Bey, kumar oynayan, kabadayılık, pehlivanlık eden bir kişi olmakla birlikte etrafına da kendi çevresinden insanları toplamıştı. Bunlar arasında Ziya'nın biraderi Hakkı ve özellikle Topal Tevfik önemli kişilerdi. Yüzbaşı Kazım farmasonluk ve Siyonizm'in milli menfaatlere uymadığı ve yayılmaya başladığını, İttihat ve Terakkicilerin bu cereyanlara kapılan kişiler olduğunu söyleyerek halk arasında İttihatçılar aleyhine propaganda yapacaktı. Ahmet ve Ragıp gibi kişiler de bu propaganda yapma işinde görevlendirilmişlerdi. Kazım, Çerkezler arasında taraftar toplayarak, bunların intikam alma hislerinden yararlanmaya çalışmışı. Kazım bu şahısların bir kısmına yemin ettirerek cemiyete almış ve yapacakları işe göre bu kişilere para vermişti. Kazım ele geçirildiğinde üzerinde bulunan Romanya banknotları da bu teşebbüsünü ve rolünü doğrulamaktaydı. ${ }^{26}$

Kazım, suikasttan önce bir inkılap ve ihtilâl yapmak istemişti. Bu işi birçok noktadan araştırmıştı. Buna göre Harbiye Nezareti'ne gidilecek, Nazır Paşa'yı odasına hapsederek tutuklayacaktı. Telefonla vükelayı çağırarak onları da etkisiz hale getirmek suretiyle de inkılabı gerçekleştirecekti. Fakat daha sonra bu fikrinden vazgeçerek bir başka plan hazırlamıştı. Mahmut Şevket Paşa, Cemal Bey, Azmi Bey, Nesim Roso ve Emmanuel Karasu'yu katlederek bunların Siyonist ve farmasonluğa sahip çıktıları için öldürüldüğünü yayacaktı. Kazım, Prens Sabahattin Bey ile irtibat kurarak onun adamlarından Kemal Mithat Bey ile münasebette bulunmuş ve onun idaresinde bulunan grupları da kendi bünyesine katarak bunları da silahlandırmıştı. Plan gerçekleşirse Kamil Paşa riyasetinde bir kabine kurulması kararlaştırılmıştı.

Suikastın planlamasını Kazım yapmıştı. Önce cinayeti yapacak grupları belirlemişti. Buna göre Ziya ve Nazmi Bey riyasetindeki grup Beyazıt'ta Mahmut Şevket Paşa'nın katline tayin edilmişti. Bunlardan başka Topal Tevfik, Abdullah Safa, Hasan Şevki, Mülazım Mehmet Ali Efendiler de bu gruba katılacaklardı. Aynı zamanda Abdurrahman'ın sevk ve idaresinde bulunan otomobilin şoförü olarak Cevad Bey görevlendirilmişti. Bunlar Beyazıt civarındaki Safa Çeşmesi önüne geleceklerdi. ${ }^{27}$ Buranın seçilme nedeni ise Mahmut Şevket Paşa'nın otomobilinin buraya gelişinin gözlemlenmesinin kolay olacağı ve ona göre tertibat alınacağı ve buranın dört yol olmasından yararlanılarak kaçma firsatı yaratılacağındandı.

Hükümet bu suikasttan haberdardı. Ancak daire içinde olacağı istihbaratınındın dolayı ona göre tertibat alınmıştı. Otomobil üzerinde böyle bir suikast ihtimali düşünülmemişti. Bu sırada

25 BOA, DH.KMS. 63/63-3

26 BOA, DH.KMS. 63/63-4

27 BOA, DH.KMS. 63/63-5 
orada tesadüf eseri bulunan bir cenaze geçişinden dolayı yol kapanınca Mahmut Şevket Paşa'nın otomobili de durmak zorunda kalmış ve zanlılar kolayca emellerine ulaşmışlardı. Nazmi, Ziya, Topal Tevfik ve Abdullah Safa silahla saldıranlar arasındaydı. Diğerleri de takibi zorlaştırmak için polisin arkasından silah atmışlardı. Daha sonra zanlıların ifadesi ve şahitler sayesinde olay aydınlatılmıştı.

Vukuat sonrasinda Nazmi ve Ziya Aksaray'a firar ederken, bindikleri otomobil Cevad ve Abdurrahman tarafından sevk ve idare olunmuştu. Ortaya çıkan ihtiyaç üzerine Cevad otomobile su koyarken buharın tesirinden yüzü yanmış ve tutuklanması sırasında yanık yüzü şahitlerin ifadesi ile kendinin kolaylıkla teşhis edilmesini sağlamıştı. ${ }^{28}$

Suikastın faillerinden Tevfik kaçamamıştı. Kendisinin otomobilin basamağına çıkarak ateş ettiğine, bekçiler ve diğer kişiler şahitlik etmişlerdi. Bir gusülhanede silah ve fişeğini atmış bir şekilde yakalanmıştı. Webley ve Smith Wesson marka olmak üzere iki çeşit tabanca kullandığ tespit edilmişti. Bu tabancaları Galata'da Mehmet Efendi'nin mağazasından aldığı ve Webley marka tabanca ile ateş ettiği anlaşılmıştı.

Yapılan tahkikat ve incelemelere göre cinayet işine memur edilen çetelerin şu şekilde sevk ve idare edildiği ortaya çıkmıştı: Kara Ahmet, Kavaklı Mustafa, Raif, Laz Ali ve Edhem ile birlikte Nesim Roso Efendinin ve Ziya'nın biraderi Hakkı ve Ali, Ragıp ile birlikte Karasu Efendi'nin ve Gekbuze (gebze) Jandarma Kumandanlığı'ndan mütekaid Mehmet Bey ve arkadaşları ise İstanbul Muhafızı Cemal Paşa'nın ve Kazım'ın biraderi Hikmet ile Jandarma Kemal de Talat Bey'i takip edecek ve katledecekti. Evvela geceleri "yatak etmek" yani pusuya yatarak nerelerde dolaştıklarını ve gece nerelerde kaldıklarını araştıracaklar ve Çarşamba günü hepsi birden faaliyete geçerek katle teşebbüs edeceklerdi.

Nesim Roso hakkında Kara Ahmet ve arkadaşlarının birlikte bir müddet Pangaltı'da bir kahvede araştırmada bulunarak apartman kapıcısından ve apartman sahibinin adamı İbrahim Bey'den bilgi toplandığı anlaşılmaktaydı. Kavaklı Mustafa ve Raif, Beyoğlu'na giderken Mahmut Şevket Paşa'nın katledildiği haberini almışlardı. ${ }^{29}$

Hakk1 ve Ragıp, Karasu Efendi'nin öğle yemeği yediği sırada kendisini takip etmişti. Bunlardan Hakkı, Galatasaray'da İştayn önlerinde polis tarafından tutuklanmıştı. Bu sırada bir ahbabını görmek için Pire Sokağı'ndaki bir eve uğramak istediğini söylemişti. Esas amacı ise mezkûr evde bulunan Şevki Efendi’ye ve Kazım'a tutuklandığını söyleyerek kendi izlerini kaybetmeleri için uyarmaktı. Evden çıkınca geri dönerek polislere teslim olmuştu. Bu suretle Pire Sokă̆ı'ndaki hane polis ekiplerince tespit edilmiş̧i. Bu sırada Mehmet Ali bu haneye gelmiş ve silahlı çatışma sonucu yakalanmıştı. Cemal Paşa ve Azmi Bey'i öldürme teşebbüsünde bulunacak adamlar iş göremeyeceklerini anlayarak bu eve dönmek isteyince onlar da yakalanmışlardı.

Kazım'ın düşüncesine göre ihtilâl başarıya ulaştıktan sonra saraya gidilmesi kararlaştırılmıştı. Miralay Kemal, Miralay Fuat ve Kaymakam Zeki Bey arasında İstanbul Muhafızlığı ve Merkez Kumandanlığı gibi önemli mevkiler bölüşülmüştü. Bu makamların elde edilmesi ile birlikte tasarlanan ihtilâl hareketi başarıya ulaşacaktı. ${ }^{30}$

$\begin{array}{ll}28 & \text { BOA, DH.KMS. 63/63-6 } \\ 29 & \text { BOA, DH.KMS. 63/63-7 } \\ 30 & \text { BOA, DH.KMS. 63/63-8 }\end{array}$


Pire Sokağı'ndaki evin basılması ile Kazım Efendi ve arkadaşları tutuklanmıştı. Ancak bu cemiyet hakkında başka incelemelerin de yapılması gerekmekteydi. Damat Salih Paşa'nın Avrupa'dan alınmasına aracılık ettiği paraların, Muhib Bey tarafından getirildiği ve bu sırada Reşit Bey ile mektuplaşıldığ 1 da tespit edilmişti. Damat Salih Paşa bunu inkâr etmişti. Gözlüklü Emin, Muhib Bey, Aziz Nuri ve Özellikle Mehmet Ali Efendi'nin ifade ve itirafları sonucunda Damat Salih Paşa'nın suçlu olduğu ortaya çıkmıştı. ${ }^{31}$ Bundan sonra Damat Salih Paşa, Muhib Bey'in yakın zamanda bir inkılap yapacağını ve birçok adamın katlolacağını bildiğini beyan ederek bunu da Nuri Bey'in hanesinde Muhib Bey'den işittiğini ifade etmişti. Ancak alınan ifadelerden Muhib Bey'in böyle bir beyanda bulunmadığı anlaşılmıştı. Prens Sabahattin Bey'in de bu olayda mühim bir rol oynadığı yapılan tahkikat sonucu ortaya çıkmıştı. Şerif Paşa da Prens Sabahattin kadar para yardımında bulunmuştu.

Katillerin planlama sırasında ihtilâl sonrasında hükümet makamlarının nasıl paylaşılacağı konusunda anlaşmazlıklar yaşadıkları anlaşılmaktaydı. Prens Sabahattin Bey’in sadarete getirilmesi bu planlamalar sırasında gündeme gelmiş fakat daha sonra vazgeçilmişti. Kemal Bey’in akdettiği bu durumdan Prens Sabahattin'in de haberdar olduğu anlaşılmaktaydı.

İhtilalin planındaki bir diğer bir önemli husus ise Kemal Mithat Bey ile Kazım Efendi arasında bu ihtilâlin bir nota ya da beyanname ile sefaretlere bildirilmesi ve yabancıların kendilerini huzur içinde hissedebileceklerinin söylenmesi olacakt1. ${ }^{32}$ Kemal Mithat Bey’e notanın tanzim ve düzenlenmesi işi bırakılmıştı. Dönemin güçlü devletlerinden olan Avusturya sefaretine verilen notanın bir nüshası ele geçirilmiş burada inkılabın nasıl yapılacağının anlatıldığı görülmüştü. İttihat ve Terakki iktidarı yıkılmak istenmiş ve sefaretlerden, gemilerinden İstanbul'a asker çıkararak İstanbul'un asayişinin sağlanması ve ihtilâlin desteklenmesi istenmişti. Suikastın gerçekleşeceği Çarşamba gününün tarihi ve saatine kadar sefaretler uyarılmış ve bilgilendirilmişti.

Bu girişimde Pertev Tevfik muhaberatta etkili olmuştu. Gümülcineli İsmail ise ordu ile temasa geçerek taraftar bulmaya çalışmıştı. Yüzbaşı Adil Bey vasıtasıyla Miralay Kemal ve Fuad Beyler'e haber gönderilerek cemiyete dâhil edilmişlerdi. Bunlar aralarında suikastın planını bir kroki çizerek belirlemişler ve kimseye söylemeyeceklerine dair yemin etmişlerdi. İhtilal başarıya ulaşırsa, Kemal Bey İstanbul Muhafızı, Zeki Bey Merkez Kumandanı ve Fuad Bey de Erkân-1 Harb Riyaseti vazifelerini üstlenecekti. Süleyman Paşazade Adil Bey de bu oluşum içerisinde yer almıştı. Pertev Tevfik olayı sevk ve idare etmişti. Bu planı Reşit, Salih Paşa yardımıyla Kazım'ın avanesi ile birlikte icra etmişti. Jandarma Sadık, Jandarma Kemal ve Gözlüklü Emin Salih Paşa ile temas kurmuşlardı. Gözlüklü Emin aynı zamanda Salih Paşa'nın diğerleri ile irtibatını da sağlamıştı. ${ }^{33}$

Polis tahkikat raporlarından da anlaşılacağı üzere askeri, sivil, siyasi, padişah ailesine mensup ve sıradan pek çok kişi bu suikast planına dâhil olmuşlardı. Bunların arasında bir hükümet değişikliği yapmak düşüncesi ile harekete geçenler olduğu gibi şahsi ihtiraslar ve ailevi nedenlerle de hareket edenler vardı.

Mahmut Şevket Paşa suikastında önemli olan tartışma konuları arasında daha önce bu suikastın haber alındığ yumularak İttihatçıların Paşa'dan kurtulmak isteğinde olup olmadıkları yer alır. Aslında bir suikast

31 BOA, DH.KMS. 63/63-9

32 BOA, DH.KMS. 63/63-10

33 BOA, DH.KMS. 63/63-11, BOA, DH.KMS. 63/63-12 
olacağı haber alınmış, Mahmut Şevket Paşa, Enver ve Cemal Paşalar arasındaki görüşmelerde bu İhtilal ve suikast konularından da bahsedilmişti. Hatta İstanbul Muhafızı Cemal Bey suikastçıların hazırlıklarını tamamladıklarını artık harekete geçmelerinin saat ve gün meselesi olduğuna da işaret etmişti. Bu konuda Mahmut Şevket Paşa'yı uyarmaya gittiğinde Paşa'nın, işin olacağına varacağını ve Allah'ın takdirinin olacağını söylemesi ve konuyu çok da ciddiye almaması üzerine geri dönmüştü. ${ }^{34}$ Tarık Zafer Tuna'ya bu konuda Mahmut Şevket Paşa'nın arasının İttihatçılarla bozuk olduğu kabul edilse bile bu durumun bir meydan okumaya dönüşmesi nedeniyle pek gerçeğe uymadığını belirtir ve bunu Mahmut Şevket Paşa'nın Babıali Baskını sonrasında sadrazamlığı kabul etmiş olması ile izah eder. Ayrıca 'Paşa 1913’te otoritesini ve tarafsızlı̆̆ını yitirmişti ve artık İttihatçı sayılabilirdi” diyerek bu konuda Paşa'nın gözden çıkarılmamış olduğu yönünde fikir beyan eder. Ayrıca Azmi Bey de Mebusan Meclisi'nde yaptığı bir açıklamada durumun genel bir ihtilâl niteliği taşıdığından, sadece Mahmut Şevket Paşa'nın değil başka kişilerin de suikastçıların hedeflerinde olduğundan, suikastın yapılacağının bilindiğinden ancak yerinin tayin edilemediğinden de bahsetmiş̧tir. ${ }^{35}$ Konu ile ilgili tartışma noktaları belgelerden de anlaşılacağı üzere Paşa'nın gözden çıkarılması ihtimalini ortadan kaldırmaktadır. Buna göre Mahmut Şevket Paşa'nın makamında bir suikast düzenleneceği düşünülmüş ve buna göre tertibat alınmıştı. Yani otomobil içerisinde bir suikast olacağı akla getirilmemişti.

Suikastın gerçekleşeceği gün suikastçıların, yabancı elçiliklere gönderecekleri bildiri ise konu açısından önem taşır. Yapılan plan gereğince bu oluşum içerisinde fedailer ayrılmış ve silahlandırılmıştı. Bunlar aynı zamanda ayrı ayrı yerlerde Talat Paşa, Cemal Paşa, Nesim Roso, Emmanuel Karasu gibi İttihat ve Terakki'nin tanınmış önemli kişilerini ve ondan sonra rastlayabildikleri İttihatçıları da öldüreceklerdi. Böylece şehirde terör havası yaratacaklar ve sonra ellerinde bayraklarla bundan 31 Mart Olayı'nda olduğu gibi "şeriat isteriz" sloganları ile halk1 ayaklandırıp Babıali Baskını'na karşı bir hamle yapacaklardı. Bu sırada Müşir Şakir Paşa, Sadrazam Kaymakamı olarak atanacaktı. Sadrazamlığa Prens Sabahattin ya da Kamil Paşa getirilecekti. Bunlar olup biterken eylemin başarılı olacağına inanan Kemal Mithat Bey yabancı elçiliklere bir beyanname, bildiri ya da nota gönderecekti. "Bir tabur serseri” olarak nitelendirdikleri İttihatçıların iktidarına son vermek ve hükümeti değiştirmek için tertip etmiş oldukları planlarını fiile geçirmeye karar verdiklerini belirterek, asayişin muhafazası için sefirlerin İstanbul' daki gemilerinde bekleyen bahriye askerlerini karaya çıkararak, kendilerine destek olmalarını istemişlerdi. Asayişin muhafazası için yabancı yardımı gerekliydi. Zaten bu durum Avrupa'nın menfaatlerine de uygundu. Ayrıca bu bildiriye göre Sultan Reşat ha'l edilecek yerine Vahideddin tahta geçirilecekti. ${ }^{36}$ Anlaşılacağı üzere memlekette bir ihtilâl yapmayı düşünenler İttihatçıları iktidardan uzaklaştırabilmek için gözlerini karartmış, Osmanlı’nın başkentinin işgale uğramasına bile razı olmuşlardı.

Bütün bu olaylar içinde yabancıların rolü de vardı. İngiltere Sefareti Baştercümanı Fitzmaurine ile askeri ataşesi Binbaşı Tyrrel'in Prens Sabahattin'i korumaları, Fransız Sefiri Bompard'a vekâlet eden Boppe ve Reji Müdürü Weil'in Damat Salih Paşa'nın affedilmesi için araya girmeye çalışmaları, Satvet Lütfi'nin Avusturya Sefareti tercümanlarına sığınması, suikastçıların gizlendikleri Beyoğlu'ndaki evin yabancı tebaadan birine ait olması ve kapitülasyonların etkisi ile bu devlet yetkililerine izahat verilmek zorunda kalınması bunun göstergesidir. ${ }^{37}$

$\begin{array}{ll}34 & \text { Bayar, age, s.110 } \\ 35 & \text { Tunaya, age, s.571-518 } \\ 36 & \text { Bayar, age, s. 111-112, Tunaya, age, s. 518 } \\ 37 & \text { Tunaya, age, s. 519, Cemal Paşa, age, s. 20-29 }\end{array}$




\section{4- SUIKKASTIN FAİLLERİ VE VERİLEN CEZALAR}

Kamil Paşa Hükümeti, iktidar mevkiinde iken birbirini tenkit eden muhalifler, onun sadaretten düşmesi ile rahatsız olmuş ve tekrar onu sadarete geçirerek elden kaçırdıkları firsatı yeniden yakalamak isteğinde birleşmişlerdi. Bunlar arasında ayrılık noktaları daha ilk zamanlarda bile mevcuttu. Hürriyet ve İtilâf Fırkası'ndan Gümülcine İsmail Bey faaliyete geçmiş, Miralay Sadık Bey’le Damat Salih Paşa ise iş sahasını daha da genişletmişti. Çeşitli sınıflar arasında irtibat tesis etmeye yönelik gizli toplantılar yapılmaya başlanmıştı. Doktor Nihat, Reşat ve Satvet Lütfi Beyler, Prens Sabahattin Bey etrafında toplananlar arasındaydı. Gümülcineli İsmail Bey ise Muhib, Pertev Tevfik ve Taceddinzâde Hakkı Beyler'le beraber çalışıyordu. Sadık Bey ile Damat Salih Paşa da Hürriyet ve İtilâf Fırkası unsurları ile bunlara katılmışlardı. Görüleceği üzere muhtelif gruplar faaliyetteydi. İttihat ve Terakki aleyhinde propaganda yapiliyordu. Bu faaliyetler bazen bir plan dâhilinde bazen de plansız anlık kararlarla oluyordu. Ancak bu oluşum, disiplinli bir teşkilat olmaktan çok uzaktı. Merkezsiz, başsız, karmakarışık bir heyecan dalgası içinde devam edip gidiyordu. ${ }^{38}$ Prens Sabahattin'in adamlarının ihtilâl girişiminin anlaşılması üzerine Ahmet Bedevi ve Satvet Lütfi tutuklanmış, bunların yerini Muhip Bey almaya çalışmış ise de o da tutuklanınca Yüzbaşı Kazım ihtilâl hareketini devam ettirmişti. Adamlarının tutuklanması ile kendini olaydan geri çeken Prens Sabahattin'in yerini de Damat Salih Paşa ve Şerif Paşa doldurmaya çalışmıştı.

Mahmut Şevket Paşa suikastının failleri zorla ve gayrimeşru yollarla bir "taklib-i hükümet" yapmak memlekette genel bir isyan çıkarmak ve bir suikast tertip ederek devletin önemli görevlerindeki kişileri ortadan kaldırmak üzere teşekkül eden bir “cem’iyyet-i şekavet” yani kötü bir cemiyet kurma ile suçlanıyorlardı. Bu kişilerin her biri başlarında bulunan bir liderlerinin riyasetinde olmak üzere çeşitli gruplara ayrılarak, bu gruplar vâsıtasıyla bir ihtilâl yapmak ve faaliyete geçmek üzere bir “cem'iyyet-i hafiyye” teşkil etmek, amaçlarını icra ve tatbik etmek için 11 Haziran’da faaliyete geçmekle itham edilmişlerdi. Aynı zamanda silah tedarik ederek Sadrazam ve Harbiye Nazırı Mahmut Şevket Paşa’ya beş, yaveri İbrahim Bey’e iki kurşun atarak ölmelerine neden olmak, Kâzım Efendi'yi de yaralamak ve planlı bir cinayet ve ihtilâl için Talat, Cemal ve Azmi Beyler, Karasu ve Nesim Roso’yu katle karar vermek ve bu kişileri takip ederek planlarını gerçekleştirme yönünde harekete geçmekle yargılanıyorlardı. Beyoğlu'ndaki Ağa Camii'nde, Pire Mehmet Sokağı, bir numaralı hanede, asker ve inzibata karşı ateş açmak suretiyle muhalefet ettikleri, İstanbul Muhafizlığı yaverliğinde müstahdem Yüzbaşı Hilmi Efendi’yi revolver kurşunuyla cerh ve katlettikleri ve Polis Müdiriyet-i Umumiyesi K1sm-1 Adli Müdürü Samuel Efendi'yi ise yaraladıkları gerekçesiyle yüzüne karşı (vicahen) ya da gıyaben yargılanmışlardı. ${ }^{39}$ Faaliyeti yapanların oluşumları "cemiyet-i hafiyye", "cemiyet-i şekavet" "cemiyet-i mezkure", "çete" olarak da adlandırılmıştı. ${ }^{40}$

Yukarıdaki suçlara istinaden yapılan yargılanmalar sonucunda ceza alan kişiler, cezaları ve yargılanma şekilleri şöyleydi (Ek 3) : $:^{41}$

$\begin{array}{ll}38 & \text { Kuran, age, s. } 322 \\ 39 & \text { BOA, Bâb-1 Âlî Evrak Odası (BEO). 4188/ } 314072 \\ 40 & \text { BOA, DH. SYS. 119/1-5, 19, BOA, İrade Harbiye (İ. HB). 145/32- 1,2 } \\ 41 & \text { BOA, DH. SYS. 119/1- 5, } 4\end{array}$


Prens Sabahaddin Bey

Şerif Paşa

Reşid Bey

Gümülcineli İsmail Bey

Damad Salih Paşa

Erkân-1 Harbiye Miralay1

Fuad Bey

Kemal Midhat Bey

Pertev Tevfik Bey

Kaymakam Zeki Bey

Yüzbaşı Kâzım Bey

Muhib Bey

Hakk1 Bey

Topal Tevfik

Şevki

Mehmed Ali

Abdullah Sofa

Nazmi

Abdurrahman

Cevad

Kemal

Hikmet

Ziya

Jandarma Yüzbaşılığından

Mütekaid Mehmet Efendi

Kavaklı Mustafa

Kara Ahmed

Ragip

Raif

Gözlüklü Emin

Süleymen Paşazade

Adil
Esbak Dahiliye Nazırı

Gümülcine meb'usu sabık1

Erkân-1 Harbiye Dairesi Şu'be-i Merkeziyye Müdürü

Polis Müdiriyeti Kısm-1 Siyasi

Müdir-i esbâk1

Kantar İdaresi'nden Kadro harici

Kahveci

Bahriyeden matrud

Piyade Mülâzım-1

Evvelliğinden Müteakid

Gelenbevi İdadisi Mubassırı

Otomobilci

Şoför

Van Vilâyeti Jandarma

Efradından

Tütün kaçakçısı

Sâbık polis Müfettişlerinden

26. Alay 1. Tabur

3. Bölük yüzbaşısı
Giyaben I'dam

Giyaben I'dam

Gryaben I'dam

Giyaben I'dam

Vicahen I'dam

Vicahen I'dam

Gryaben İ'dam

Giyaben I'dam

Giyaben I'dam

Vicahen I'dam

Vicahen I'dam

Vicahen I'dam

Vicahen I'dam

Vicahen I'dam

Vicahen I'dam

Vicahen I'dam

Giyaben I'dam

Gryaben I'dam

Vicahen I'dam

Vicahen I'dam

Gryaben I'dam

Vicahen I'dam

Gryaben I'dam

Gryaben I'dam

Vicahen on beş sene kürek

Vicahen on beş sene kürek

Gıyaben on beş sene kürek

Vicahen müebbed kal'a-bend

Vicahen müebbed kal'a-bend

Giyaben müebbed kal'a-bend 
Yukarıda görüldüğü üzere Prens Sabahattin, Reşit Bey, Şerif Paşa, Gümülcineli İsmail Hakkı, Damat Salih Paşa, Miralay Fuad Bey, Kemal Mithat Bey, Kaymakam Zeki Bey, Yüzbaşı Kazım Efendi ve Muhib Bey cemiyetin esasını teşkil eden kişiler olarak görülmüştü. Bu nedenle bu kişilerin Mülkiye Ceza Kanunu'nun 56. ve 57. maddelerine göre idamlarına, karar verilmişti. Bu karar 23 Haziran 1913'de Padişah tarafından yayınlanan irade ile de onaylanmıştı. ${ }^{42}$ Ayrıca Ziya, Topal Tevfik, Şevki, Mehmet Ali, Abdurrahman Safa ve Cevad Beyler gibi bu ihtilâl ve suikasta silahlanarak doğrudan doğruya katılan ve cürümü işleyen kişiler de katlin faili olmaları gerekçesiyle idam cezasına çarptırılmışlardı. Yine bu kişilerin maiyetinde iş gören Jandarma Kemal, Jandarmadan mütekaid Mehmet Bey ve Kavaklı Mustafa'ya da Kanunnamenin 56 ve 57. maddelerine göre idam cezası verilmişti ve bu karar Padişah tarafından 28 Kasım 1913 tarihinde onaylanmıştı. ${ }^{33} \mathrm{Hakk}$ ve Kavaklı Mustafa maiyetinde olan Ragıb, Kara Ahmet ve Raif'e ise kanunnamenin 57. maddesi mucibince 15 'er sene kürek cezası verilmişti. Bu cemiyetin faaliyetlerine iştirak eden ve Damat Salih Paşa ile irtibat ve muhabere sağlayan, bunlardan Nazmi'nin mülakatını yapan, Fuad Bey'in cemiyet ile temas ve münasebetini sağlayan Gözlüklü Emin ile Süleymanpaşazade Adil Bey ise müebbet kalabentlikle cezalandırılmışlardı. Erkan-1 Harbiye Miralayı Kemal Bey, Mektebi Hukuk talebesinden İzzettin ve Yüzbaşı Adil Efendiler, Şoför İsmail, Şoför Mehmed, Jandarma Sadık, Kasabın Fehmi ve Şeyhlili Mustafa'nın da bilerek suç işleyip işlemediklerine karar verilemediğinden beraatlarına karar verilmiş ve bu karar Divan-1 Orfi tarafindan tasdik olunmuştu. ${ }^{44}$ İttihat ve Terakki>ye muhalefet eden ikiyüz kişiyi aşkın bir grup da Sinop'a sürgün edilmişti. ${ }^{45}$

$\mathrm{Bu}$ ihtilâl ve suikast hareketinin haber alınması sırasında bilindiği üzere Satvet Lütfi, Serdarzade Sadkı, Hasan Vasfi, Muşlu Said, Ahmet Bedevi, Müfettiş Sıdkı, Mülazım Lütfi tutuklanmışlardı. Bunlar hakkında Divan-1 Harb-i Örfisi'nde verilmiş olan müebbet ve kalebentlik cezaları Padişah tarafından 1 Haziran 1913'te tasdik edildi. ${ }^{46}$

$\mathrm{Bu}$ suikastı gerçekleştirenlere yardım ve yataklık suçlarından yargılanan; Akyazılı Kaspoladoğlu Sarı Mehmet Kemal, Karlovalı Ömer Şevki, Kasap Abdüllatif, Sofyalı Edip, pasaport memuru Cemil ve hukuk mektebinden mezun Kayserili İsmail Hakkı'nın yargılanmaları sonucunda çeşitli cezalara çarptırılmış ve Dersaadet Divan-1 Harb-i Örfisi'nden verilmiş olan kararlar da Padişah tarafından 15 Mart 1914'te tasdik edilmişti. ${ }^{47}$

Yargılananlar arasında bulunan Tunuslu Hayrettin Paşa'nın oğlu olan Damat Salih Paşa'nın idam kararı oldukça önemliydi. Paşa'nın Fransa üzerindeki nüfuzu dolayısıyla Fransa Hükümeti'nin tepki göstereceği endişesi yanı sıra Osmanlı Hanedan ailesine mensup bir damadın bu şekilde cezalandırılması tartışmalara konu olmuştu. Ancak Cemal Paşa cezayı uygulatmak için padişahı zorlamış ve hatta onu tahttan indirmekle tehdit etmiş̧i. ${ }^{48}$

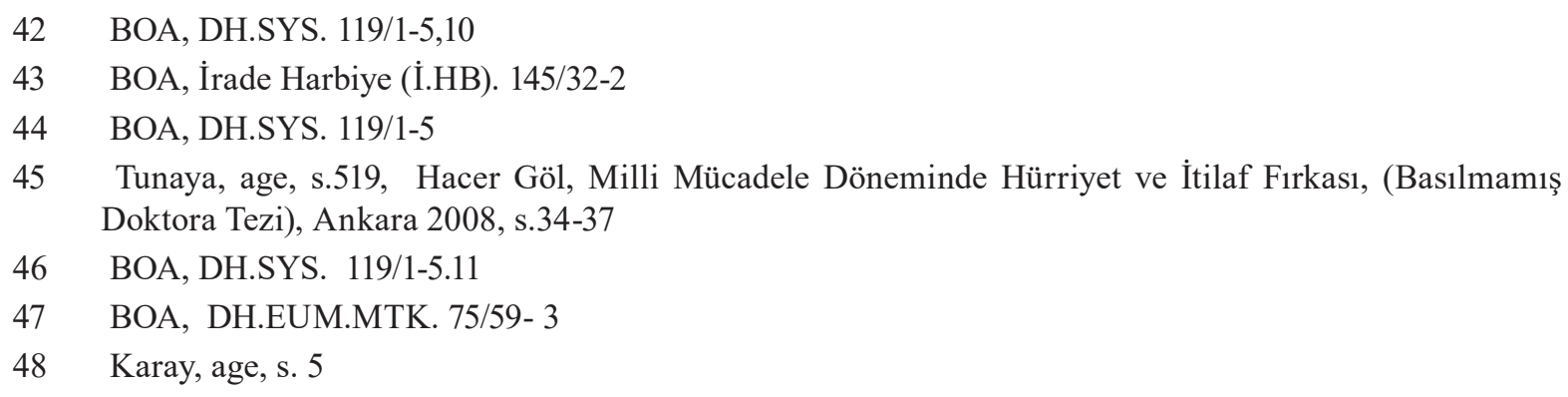


Mahmut Şevket Paşa suikastı üzerine Hürriyet ve İtilâfçıların yayın organı olan Alemdar Gazetesi kapatılmış, gazetenin başyazarı Ref'i Cevat İstanbul'dan uzaklaştırılmıştı. Sırasıyla Sinop, Çorum ve Konya'ya sürgüne gönderilmişti. Bu ihtilâl girişiminden sonra kurulan hükümetler de İttihat Terakki Cemiyeti’nin ağırlığı ise gittikçe artmıştı. ${ }^{49}$

Mahmut Şevket Paşa'nın cenaze töreni yaşanan hadiselere rağmen bekletilmemiş hemen suikastın ertesi günü yapılmıştı. Tertip edilen törene yabancı devletlerin elçilerinin ve İstanbul'da bulunan deniz kuvvetleri kumandanlarının da davet edilmesi, suikastçıların henüz yakalanmadığı düşünüldüğünde oldukça riskli bir işti. Çünkü ihtilâlciler den biri bu alana saldırsa ve bir elçinin ya da kumandanın yaralanmasına ya da ölümüne neden olsa Osmanlı başkentinde bekleyen savaş gemilerinin mürettebatı tarafından şehrin işgal edilmesi kaçınılmaz olurdu. Fakat İttihatçılar hiç tereddüt etmeden kendilerine güvendiklerini ve aldıkları tedbirlerden emin olduklarını göstererek bu merasimi düzenlemişlerdi. Katillerin kısa zamanda yakalanacağı ve İstanbul'un emniyet altında olduğunun mesajını vermişlerdi. ${ }^{50}$ Düzenlenen törenle Mahmut Şevket Paşa Meşrutiyet idaresinin tarihi bir siması olarak 57 yaşında Hürriyet-i Ebediye Tepesi'ne gömüldü.

\section{SONUÇ}

Babıali Baskını'ndan sonra Sadrazam ve Harbiye Nazırı olan Mahmut Şevket Paşa yaklaşık dört ay görevde kalabilmişti. 11 Haziran 1913'de otomobili ile Harbiye Nezareti'nden Babıali'ye gitmek üzere yola çıktığı esnada suikasta kurban gitmişti. Bu suikast Osmanlı Tarihi açısından bir sadrazam ve Harbiye Nazırı'na karşı planlı olarak hazırlanan ve siyasi, askeri, sivil çeşitli kesimlerden pek çok kişinin katıldı̆̆ ilk suikast olarak kabul edilebilir. Ayrıca hanedan ailesinden Prens Sabahattin ve Damat Salih Paşa gibi kişilerin bu girişimi desteklemesi de oldukça önem taşır. Mahmut Şevket Paşa suikastı, Meşrutiyet tarihimizin siyasal hayatında aynı zamanda bir dönüm noktasını da teşkil eder. Çünkü İttihat ve Terakki Cemiyeti artık tek parti olarak Osmanlı siyasi hayatındaki yerini korumuş, muhaliflerini kontrolü altına almıştır. Bundan sonra daha rahat ve serbest bir şekilde siyasi hayatta faaliyetlerine devam etmiştir.

Mahmut Şevket Paşa'ya yapılan suikastın aslında sadece Paşa'yı öldürmekle sınırlı olmadığı İttihatçıların yönetimine son vermek için bir "taklib-i hükümet” girişimi olduğu görülmektedir. Talat Paşa, Cemal Paşa ile Emmanuel Karasu, Nesim Roso gibi önemli İttihatçılar da hedef alınarak öldürülmek istenmiştir. Ülke içerisinde bir ihtilâl çıararak Prens Sabahattin veya Kamil Paşa riyasetinde İttihatçıların yer almadığı bir hükümet kurmak yolunda hareket edilmiştir. İstanbul Muhafızlığı, Harbiye Nazırlığı gibi görevlere kimlerin geçeceği bile tartışmalı da olsa belirlenmiştir. Glavani ve Pire Sokağı'ndaki evler suikastçıların teşkilatlandıkları ve toplandıkları yerler olarak belirlenmiştir.

Yapılacak olan ihtilâl hareketi için Prens Sabahattin, Damat Salih Paşa ve Şerif Paşalardan maddi olarak destek alınmıştı. Prens Sabahattin'in adamlarının yakalanmasından sonra olaylardan geri durduğu ve onun boşluğunu Damat Salih Paşa ve Şerif Paşa'nın doldurduğu görülmekteydi. Ayrıca Ahmet Bedevi, Satvet Lütfi ile başlayan bu hareket Muhip ve Kazım Beyler'in adeta bayrağı devralmaları ile elden ele devam etmiş̧ti. Bu girişimler içerisinde Prens Sabahattin Bey 
kan dökmeden miting ve protestolarla bir ihtilâl yapmayı tasarlamış ancak diğer girişimler ise çok da masum olmamıştı. İttihatçılar kuvvetli istihbarat örgütleri sayesinde bu faaliyeti haber almışlar ve suikasttan önce birçok kişiyi tutuklamışlardı. Cemal Paşa tarafından Damat Salih Paşa da olay öncesinde çağırılarak uyarılmıştı. Ancak Damat Salih Paşa bu uyarıları ciddiye almayarak kendi sonunu hazırlayan olaylara dâhil olmuştu. Diğer taraftan yapılacak suikastların otomobil içinde olması ihtimali ise göz ardı edilmişti.

İttihatçıların Mahmut Şevket Paşa vakasından sonra sert bir tutum izleyerek bu olaya karışanları cezalandırmadaki kararlılıkları ve kendilerine karşı bir muhalefet hareketine göz yummayacaklarını göstermeleri önemlidir. Ayrıca bu durumu kendi lehlerine kullanarak, kendilerine muhalif olan kişileri bu olay vasıtasıyla cezalandırmış, başkentten uzaklaştırmış ve ortadan kaldırmışlardı. Olayın uzantıları Mütareke Dönemi'nden sonraya da yansımış özellikle Sultan Vahideddin'in tahta geçmesi ile bir intikam alma hissine dönüşmüştü. Mahmut Şevket Paşa suikastı sonucu cezalandırılan pek çok Hürriyet ve İtilâfçı bu dönemde İttihatçılara karşı sert ve intikam içeren bir politika anlayışı gütmüşlerdi.

Mahmut Şevket Paşa suikastı bir başka açıdan İttihatçıların Paşa'dan kurtulmak istemeleri ve bu yüzden onun ölmesine göz yumdukları yönüyle de tartışılmıştır. Bu düşüncelerin ortaya çıkmasında zaman zaman Mahmut Şevket Paşa'nın İttihatçılarla ters düşen hareketleri ve özellikle mebuslar ve meclis üzerinde güçlü bir nüfuza sahip olması etkili olmuştur. Ancak İttihatçıların bu şekilde hareket ettiklerine dair bir belgeye rastlanmamıştır. Ayrıca Paşa'nın üzerinde bulunan Sadaret Makamına İttihatçıların teklifi ile geldiği ve bu görevde iken kısa zaman içerisinde suikasta uğradığı göz önüne alınacak olursa bu ihtimal suya düşmektedir.

Sonuç olarak bu suikast, her ne kadar Meşrutiyet döneminde İttihat ve Terakki Cemiyeti'nin tek başına siyasi hayata devam etmesini sağlamışsa da siyasi tarihimiz açısından çok partili hayata geçiş sancısı olarak da nitelendirilebilir. Bu partilerin iktidar-muhalefet ilişkileri açısından birbirini sindirememe ve kabullenememe durumunu içerir. İttihat ve Terakki yönetiminin iktidarını kabullenemeyen ya da ondan umduğunu bulamayıp memnun olmayan çeşitli kişiler bir araya gelerek onu devirmek istemişlerdir. İttihat ve Terakki açısından ise muhalefeti kabul etmeyerek bu suikast bahanesiyle rakiplerini sindirme yönünde hareket etmesi, İttihat ve Terakki'nin muhalefete tahammülsüzlüğünü göstermektedir. Suikastçıların emellerine ulaşabilmek için yabancı devletlerin elçilerinden kendi başkentleri İstanbul'un işgalini isteyecek kadar cüretkâr davranmaları ise konu açısından ayrı bir önem taşımaktadır. İngilizlerin, Fransızların ve Avusturyalıların olaylar sırasındaki tavırları ise suikastta yabancı parmağının olduğunun kanıtıdır.

Hem siyasi hem de askeri açıdan önemli bir kişilik olan ve Osmanlı tarihinde tartışılan Mahmut Şevket Paşa bu ihtilâl hareketi sonucunda hayatını kaybetmiş ve Hürriyet-i Ebediye Tepesi'ne defnedilmiştir. Cenazesi daha katilleri yakalanmadan birçok yabancı elçi ve deniz kumandanlarının da katılımıyla gerçekleşmiştir. İttihatçıların kendilerine olan özgüvenlerini ve İstanbul'un emin ellerde olduğunu göstermek amacıyla böyle çabuk ve kalabalık bir cenaze töreni düzenledikleri de gözden kaçmamaktadır.

Osmanlı askeri ve siyasi tarihine dâhil olmuş olan Mahmut Şevket Paşa yaşamı, icraatları ve ölümü ile daha çok kez tartışma ve araştırma konusu olacaktır. 


\section{KAYNAKÇA}

\section{ARŞIV BELGELERI}

Başbakanlık Osmanlı Arşivi (BOA) Bâb-1 Âlî Evrak Odası (BEO). 4188./314072

BOA, Dahiliye Emniyet-i Umumiye Muhaberat ve Tensikat Müdüriyeti Evr. (DH.EUM. MTK)., 75 /59- 3

BOA, BOA. Dahiliye Nezâreti Kalem-i Mahsus Müdüriyeti Belgeleri (DH.

KMS).63.63.2.1

BOA, DH. KMS. 63/ 63- 3

BOA, DH. KMS. 63/63-4

BOA, DH. KMS. 63/63-5

BOA, DH. KMS. 63/63-6

BOA, DH. KMS. 63/63-7

BOA, DH. KMS .63/63-8

BOA, DH. KMS .63/63-9

BOA, DH. KMS. 63/63-10

BOA, DH. KMS. 63/63-11

BOA, DH.KMS. 63/63-12

BOA, Dahiliye Nezareti Siyasi Kısım Evrakı (DH.SYS) 119/1-5.4

BOA, DH.SYS. 119/1-6.6,1

BOA, DH: SYS.119/1-6.6,2

BOA, DH. SYS.119/1-6.7

BOA, DH.SYS. 119/1-5.10

BOA, DH.SYS. 119/1-5. 11

BOA, DH. SYS. 119/1-5.19

BOA, İrade Harbiye (İ.HB). 145/32-1

BOA, İ.HB. 145/32-2

\section{ARAŞTIRMA ESERLERİ, ANI, MAKALE VE ANSÍKLOPEDİLER, TEZLER}

Akşin,Sina- Sarp Balcı Barış Ünlü, 100. yılında Jön Türk Devrimi, İş Bankası Kültür Yayınları, İstanbul 2010.

Bayar, Celal, Bende yazdım Milli Mücadele’ye Gidiş C.IV, Sabah Yayınları, İstanbul 1997. Cemal Paşa, Hatırat, Arma Yayınları, İstanbul 1997, 4. Baskı.

İnal, İbnülemin Mahmut Kemal, Son Sadrazamlar, C.IV, Dergah Yayınları, İstanbul 1982, 3. Bask1, s. 1869-1881.

Göl, Hacer, Milli Mücadele Döneminde Hürriyet ve İtilaf Fırkası, (Basılmamış Doktora 
Tezi), Ankara 2008.

Karay, Refik Halit, Bir Ömür Boyunca, Türk Tarih Kurumu, Ankara 2011.

Kuran, Ahmet Bedevi, İnkılap Tarihimiz ve Jön Türkler, Tan Matbaası, İstanbul,1945.

Sadrazam ve Harbiye Nazırı Mahmut Şevket Paşa'nın Günlüğü, Arba Yayınları, İstanbul 1988.

Simavi, Lütfi, Osmanlı Sarayının Son Günleri, İstanbul 1979.

Tansu, Samih Nafiz, İttihat ve Terakki İçinde Dönenler (Anlatan: Galip Vardar ), Yeni Zamanlar Yayınları, İstanbul 2003.

Tunaya, Tarık Zafer, Türkiye'de Siyasal Partiler Cilt 3 İttihat ve Terakki Bir Çağın Bir Kuşağın Bir Partinin Tarihi, İstanbul 2000, 2 baskı

Türkmen, Zekeriya, "Mahmud Şevket Paşa (1856-1913)" Türkiye Diyanet Vakfı İslam Ansiklopedisi, C. 27, Ankara 2003, s. 384-386.

Türkgeldi, Ali Fuad, Görüp İşittiklerim, Türk Tarih Kurumu Yayınları, Ankara, 2010, 5. Bask1.

Yalçın, Hüseyin Cahit, "Meşrutiyet Hatırları (1908-1918) “, Fikir Hareketleri, İstanbul 1933, say1 118, s. 212-214 .

Ziya Şakir, Mahmut Şevket Paşa, Akı1 Fikir Yayınları, İstanbul 2011. 
Ek 1: İstanbul Polis Müdiriyet-i Umumiyesi'nin 20 Haziran 1913 tarihli raporunun transkripsiyonu:

İstanbul Polis Müdiriyet-i Umûmiyesi

Tahrirat Kalemi

Umûmî: 2404 Husûsî: 91

\section{Dahiliye Nezaret-i Celîlesine}

\section{Nâzır Beyefendi Hazretleri}

Memlekette bir kıyam ve ihtilâl-i umûmi husûle getirerek bi’n-netice hükûmet-i hâzırayı esâit-i cebriye ve gayr-i meşru'a ile 1skat etmek ve bu bâbda ef'al ve tedâbire de tevessül ederek Mahmut Şevket Paşa hazretleriyle yâveri İbrahim Bey’i katl ve zât-1 âlîleriyle Cemal Bey’i ve bendenizi ve Nesim Roso ve Manuel Karasu efendileri katle teşebbüs etmek ve tahassun eyledikleri Beyoğlu'nda Pire Mehmet Sokağı'nda kendilerinin derdestine teşebbüs eden me'mûrîn-i askeriyye üzerine ateş ederek inzibat zâbitlerinden Yüzbaşı Hilmi Efendi'yi katl ve Samuel Efendi'yi sûret-i mühlikede cerh etmek gibi cerâime ictisar eden Yüzbaşı Kâzım ve rüfekası hakkında icra edilen tahkikattan hâsıl olan neticeye göre vak'anın sûret-i cereyânı ve maznunlardan her birinin cürm-i vâkı'a derece-i iştirakleri hakkında arz-1 ma'lûmat olunur.

Bir müddetten beri Prens Sabahaddin Bey tarafindan Dersaadet'te sevk ve idare edilen teşebbüssât-1 ihtilâliye geçenlerde Prens Sabahadin Bey'in Kâtib-i Husûsisi Satvet Lütfi Bey ve rüfekasının derdest edilmeleri üzerine bir dereceye kadar kesb-i atalet ederek hatta bu çetenin a'zâ-yı âmilesinden bulunan Doktor Nihad Bey Sabahaddin Bey tarafindan Atina' da esir zâbitânın ifsâd-1 efkârı zımnında mühim bir para ile o taraflara gönderilmiş ve bu teşebbüsat netâyicinde buradaki teşebbüsât-1 ihtilâliyede Pertev Tevfik Bey'in Glavani Sokağı'ndaki Müdafaa-i Milliye Cemiyeti Gazetesi idarehanesinin bulunduğu apartmanda ara sira ictima etmekte ve bu ictima'lara ekseriya Gümilcineli İsmail Bey dahi iştirak eylemekte idi. Bu faaliyet-i inkılâbiyeye isimleri haber alınıp haklarında ayrıca ta'kibat icra kılınan birçok kesan iştirak edip bu cümleden olmak üzere bir aralık bu cem'iyyete; Muhib, Kâzım, Ziya, Hakkı, Nazmi, Topal Tevfik ve Kara Ahmet vesaire gibi bugünki vakayi' in en mühim simalarından bulunan kesan dahi iştirak etmişlerdir. Sabahaddin Bey’in sarf eylediği bin yedi yüz lira kadar bir paranın gûya meslek-i siyâsisi etrafında toplanmış olan heva-perest çocuklar tarafindan israf edilmesi ve ba-husus Ahmed Bedevî vesairenin bu hususda Prens'in paralarının sarfına sûret-i fevkaladede çalıştıkları ve bu kadar mesai ve emeklere rağmen Satvet Lütfi ve Ahmed Bedevi ve sâirenin derdest olunarak Doktor Nihad Bey'in dahi Avrupa'ya gönderilmiş olması ve bu yolda da birçok masârif ihtiyar edilmesi dolayısıyla Sabahaddin Bey'in mesaisine oldukça halel-târi olmuş ve hatta Kâzım ile Muhib ve bi'l-ahere Nazmi’nin Sabahaddin Bey ile teması ve münasebetlerinde bu hakikat Kâzım tarafindan anlaşılmış idi. ${ }^{51}$ Kâzım'1n Prens nezdindeki teşebbüsâtı hüsn-i netice vermemiş ve talep eylediği bin beş yüz 
liradan bin lirasının bankaya tevdî̀ ve beş yüz liranın vakayi-i ihtilâliye ihzârına sarf olunması hakkında Kâzım tarafından vuku bulan teklif akim kalmıştır. Memlekette mutlaka bir inkılâb-1 siyâsi vücûda getirmek fikir ve niyetini kendisine emel ve nokta-i nazar ittihaz etmiş olan Kâzım bundan sonra Sabahaddin Bey’den ziyade Damad Salih Paşa ile teşrik-i mesai etmişstir.

Muhib vâsıtasıyla Damad Sallih Paşa ile te'sis-i münasebet ederek memlekette bir inkılâp ihzar etmek üzere lüzûmu bulunan mebâliğin be-heme-hal elde edilmesi zımnında Salih Paşa'nın tavassutuna müracaat olunmuştur. Dersaadet'te ta'kibâta ma'ruz olan Yüzbaşı Kâzım Bey bu paranın daha emin bir surette tedâriki esbâbını ihzar içün Romanya'ya gitmeye lüzum görmüş ve bu paranın tedariki zımnında Salih Paşa'nın tavassutunu ikmal etmiş olan Muhib Bey dahi Romanya'ya azimet etmiştir. Bir taraftan Salih Paşa'nın Reşid Bey'e tahriren vuku bulan müracaatı ve diğer tarafdan Pertev Tevik Bey tarafından Şerif Paşa ile vuku bulan muhaberat hüsn-i sûretle netice vererek Reşid Bey ile Köstence'de mülâkat vuku bulmuş ve Romanya Bankası'ndan on bin Franklık kaime akçe ahz ve tedarik olunmuştur. Paraların bir ihtilâl-i dâhili ika'ı içün sarfı zımnında olan Muhib Bey ve müteakiben Kâzım Efendi Dersaadet'e gelmişler ve burada olan Galatasaray Hamamı ittisâlindeki bir sokakta bir haneye gidilerek burada Komiser Latif Efendi isminde birisi tarafından Muhib Bey buldurularak teşebbüsât-1 vâkı'anın esaslarını vaz' etmeye başlamışlardır. Kâzım Efendi bu hanede bir top kırmızı benekli bezler tedarik edip cem‘iyyet efradına parola makamında isti'mal edilmek üzere tevzi olunmuştur.

Muhib bey tevkif edilerek faaliyet-i ihtilâliyesi bi’t-tab' münkati olmuş ve fakat Kâzım yine ihtilâl tertibâtına devam etmiş ve bunun içün ber-vech-i âti tasavvurât-1 tertîbât ve tahrikâtta bulunmuştur. Kâzım Efendi icraat-1 ihtilâliyesini kuvveden fiile getirecek eşhâsı sunûf-1 ictima'iyemizin muhtelif aksamından tedarik etmiş ve bunun içün ber-vech-i âti nukât-ı nazardan hareket etmişlerdir.

Kâzım'ın tedkik olunan tercüme-i hâline nazaran kumara ve işrete müttehimin kabadayılık iddiasında ve vaktiyle bir parça pehlivanlık etmiş bir adam olduğu cihetle evvel-emirde kendi rüfekasından bu kabil evsafi ${ }^{52}$ hâiz adamları tercih etmiş ve bunların cesaretinden ve tehevvür ve faaliyetinden istifade etmeyi düşünmüştür. Ziya biraderi Hakkı bâ-husûs Topal Tevfik ve daha isimleri ta' dâda lüzum görmediğim maznûnunaleyhim bu miyanda bulunmaktadir.

Diğer maznûnun-aleyhimden bir kısmını(n) icraat-1 hükûmeti bir sûret-i ma'kûsede tenkid etmek velhasıl vazâyifi tahrif ederek kendisini sûret-i hakdan göstermek tarikiyle külliyen halkın zihnini ihlâl eylediği görülmektedir. Kara Ahmed ve Ragıb maznûnun- aleyhimi bu kısım miyanında görmekteyiz. Yüzbaşı Kâzım memlekette Farmasonluk ile Siyonistlik menâfi-i milliye hilâfına olarak münteşir olduğundan ve İttihad ve Terakki Cemiyeti'ni temsil eden zevâtın bu cereyanlara kapılmış birtakım adamlar olduğundan bahs ile muhâtabını ikna içün Karasu Efendi'ye atfen vak'a-i hal'i tahrif ederek hikâye eylemiştir. Üçüncü kısım maznûnun-aleyhimi dahi Kâzım kendi akrabasından ve Çerkesler arasında(n) intihab ederek bunların da cehllerinden hiss-i intikamlarından istifade etmiştir.

Itma' ile te'min-i maksada vusul mümkün olamayacağını takdir eden Kâzım Efendi aynı zamanda bunlardan bir kısmına hîn-i tahlif ve cem'iyyete duhullerinde üçer Fransız lirası ve bi'ttab' diğerlerine de cem'iyyetteki mevkilerine ve ehemmiyet-i şahsiyetlerine göre daha fazla para 
vermiş ve bunlardan bir kısmının onda biri de Romanya banknotları sarf ettikleri ve Kâzım'ın üzerinin taharrisinde dahi yüzer Franklık kırk dokuz aded Romanya banknotu zuhur ettiği bi’t-tab ‘ ayrıca nazar-1 dikkate alınacak husûsâtdan görülmüştür. Kâzım Efendi paranın tedarikinden ve kendisine lâzım gelen efrâdın ihzârından sonra hemen tertibâta girişerek tasavvur eylediği inkılâp ve ihtilâlin icrasına bed' ve mübaşeret etmektedir. Kâzım Efendi vakayi-i ihtilâliyeyi birçok nokta-i nazardan tedkik ve ta'mik etmiş ve evvel-emirde avenesiyle birlikte Harbiye Nezareti'ne giderek nâzır paşayı odasına habs ve tevkif ${ }^{53}$ etmek ve telefon ile vükelâyı celp ederek bu sûretle bir inkılâp yapmak tasavvur eylemiştir. Bi'l-ahare bu tasavvurdan feragat ederek bu kerre mevki'-i tatbike vaz'eylediği programı tanzim eylemiştir. Bu program mûcibince; Mahmud Şevket Paşa zât-1 âlîleri ve Cemal Beyle bendeniz ve Nesim Roso, Karasu efendileri aynı zamanda katl etmek ve dört evvelki zevâtın katliyle inkılâbı yapmış ve iki sonrakileri katlederek ezhân-1 nâsa Siyonistlik ile Farmasonluk aleyhine hareket ettiğini göstermek fikir ve emelini ta'kib etmiştir.

Bu sıralarda Sabahaddin Bey ile tekrar te'sîs-i münasebet eden Kâzım Efendi ve Sabahaddin Bey'in adamı olan Kemal Midhat Bey'i maznûnun-aleyh bu bâbdaki münâsebâta tavassut ederek Sabahaddin namına icrâ-yı faaliyet eden ve Kemal Midhat'ın taht-1 sevk ve idaresinde bulunan grup dahi Kâzım Bey'in grubu ile te'sîs-i münasebet eylemiş ve evvelki gruba mensup bulunan Şevki Efendi Kâzım grubuna ilhak eylediği gibi bir miktar da tabanca i’ta etmiş̧ir. Bu tevlid-i mesainin, teşekkül edecek kabinenin Kâmil Paşa'nın riyaseti altında olması emeliyle vuku bulduğu da kezâlik tahkîkât-1 vâkı'adan müstebân olmaktadır.

$\mathrm{Bu}$ suretle bu iki grup namına hareket eden Kâzım Efendi vak'a-i cinâiyenin icrasına mübâşeret ederek efrâdını gruplara taksim etmiş her birerlerine vazâif-i mahsûsa tevdi etmiştir. Bu cümleden olmak üzere Ziya ve Nazmi Bey'in riyaseti altında tasdik olunan grup Bayezıd'da Mahmud Şevket Paşa'nın katline me'mur edilmiş ve burada bunlardan başka Topal Tevfik, Abdullah Safa, Hasan Şevki ve Mülazım Mehmet Ali Efendiler dahi terfik olunmuşlardır. Aynı zamanda Abdurrahman'ın taht-1 sevk ve idaresinde bulunan otomobil tedarik olunarak şoför Cevad ile birlikte Bayezıd civarındaki Safa Çeşmesi önü intihab ve buranın intihab ve ta'yini bi'l-hassa

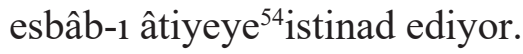

Bu kere Bayezıd Meydanı'na gelebilecek olan Mahmud Şevket Paşa'nın otomobilinin tarassudu suhûletle icra ve ona göre tertibat ahz olunabileceği dörtyol ağzı olmak i’tibarıyla firara dahi bir suhûletle nâil olmak muhakkak bulunuyordu.

Hâlbuki hükûmet vaktiyle bu vak'a-i ihtilâliyeyi haber almış ve bunun içün daire dâhilinde icra olunabileceğini nazar-1 dikkate alınarak ona göre tertibât-1 lâzıme ittihaz eylemiş idi. Otomobil önünde bir cinayet ve tecavüz icrasını hem müşkil ve hem de tehlikeli ad ediyor idi. Fi'hakîka maznûnun-aleyhimin bu şerâit dâhilinde bir cinayet ika' edebilmeleri pek baîd idi. Fakat maa'lesef bir hâdise bir tesadüf bu meş um ve felaketli vak'ayı ihzar ve teshil etmiştir. Bu sırada orada tesadüf olunan bir cenaze münasebetiyle tevakkufa mecburiyet hâsıl olmuş ve maznûnun-aleyhim bu firsattan istifade ile tasavvurlarını kuvveden fiile çıkarabilmişlerdir.

Vak'anın sûret-i cereyânı ve maznûnun- aleyhimden Nazmi, Ziya, Topal Tevfik'in ve Abdullah Safa'nın silâh isti'mal eyledikleri ve diğerlerinin dahi ta 'kibâtı eşkâl etmek üzere polisin arkasından silâh atmakta idiler. Bu bâbda maznûnun-aleyhimin ifâdâtı ve istima' olunan şühûdun

53 BOA, DH. KMS 63/63-4,1

54 BOA, DH. KMS 63/63-5,1 
şehâdât-1 sarîhaları vak'ayı tamamıyla tenvir etmiş ve daha o zamandan beri eşhâs-1 vak'anın kimlerden ibaret idüğü anlaşılarak o vak'adan i'tibâren haklarında taharriyat ve ta'kibâta şitab edilmiştir. Vuku'âtı müteâkib Nazmi ile Ziya otomobile binerek Aksaray'a doğru firar etmişlerdir. Otomobili şoför Cevad ve Abdurrahman taraflarından sevk ve idare olunmakta idi.

Bi'l-ahere yolda şoför Cevad otomobile su koyduğu sırada buharın te'sirinden yüzü yanmış ve hîn-i derdestinde kendisinin teşhisine medar bir emare hâsıl olmuştur. Maznûnun- aleyhimden Tevfik bu sırada firara muvaffak olamayarak ve yangın mahalline saparak firara başlamış ve bu sırada bekçi vesâir kesan taraflarından tamamen teşhis olunmuşlardır. Tevfik'in otomobilin basamağına basarak içeriye ateş ettiği şühûd-1 müteaddide taraflarından haber verildiği gibi elindeki tabancanın bi'l-ahere ateş almaması üzerine bunu atarak diğer bir tabancay ${ }^{55}$ bi'l-isti'mal firara teşebbüs etmiştir ki evvelce terk etmiş olduğu tabanca otomobilin basamağ edilmiştir. Tevfik firar ile o civardaki İşret-hanenin havlusundaki gusl-haneye evvelâ elindeki tabancayı ve belindeki fişenkliği attı̆̆ gibi abdest-haneye gizlenmiş ve burada kendisini ta'kib eden me'mûrîn-i zabtiye tarafından derdest olunarak gerek gusl-haneye attığı silâh ve fişenklik ve gerekse abdest-hanedeki fişenklikler elde edilmiştir.

Abdest-hanede bulunan fişenkler gusl-haneye (gasilhane) atılmış olan tabancanın fişenkleri olduğu gibi şarjörleri tamamıyla otomobilin basamağı üzerinde terk eylediği Webley tabancasının şarjörüdür. Diğer taraftan bu silâhlar hakkında icra kılınan tedkikata göre maznûnun-aleyh Tevfik'in üzerinde zuhûr eden ve Galata'daki Mehmed Efendi'nin silâh mağazasından icra kılınan tedkikatdan, Smith Wesson nev'inden bulunan ve ekserisi kırmızı saplı olan silâhların bu mağazadan Tevfik tarafından mübayaa edildiği tahakkuk etmiştir.

Tedkîkat ve tahkîkât-1 vâkı' aya göre aynı günde icrâ-yı faaliyete me'mur çetelerin ber-vech-i âti tertip ve sevk ve idare edildiği tezahür ediyor. Ez-cümle maznunlardan; Kara Ahmed diğer maznun Kavaklı Mustafa, Raif, Lâz Ali ve Edhem ile birlikte Nesim Roso Efendi'nin ve Ziya'nın biraderi Hakkı ve diğer maznun Aliye Ragıb ile birlikte Karasu Efendi'nin ve Gekbuze (Gebze) Jandarma Kumandanlı̆̆ı'ndan mütekaid Mehmed Bey diğer rüfekası ile İstanbul muhafızı beyin ve Kâzım Efendi'nin biraderi Hikmet Efendi ve hatta Jandarma Kemal, Talat Bey'in ta'kib ve katline me'mûr edilerek evvelâ geceleri "yatak etmek" ta'biriyle nerelerde dolaştıklarını ve gece nerede kaldığını tahkik ederek ertesi Çarşamba günü kendilerini bi’t-ta'kib katle teşebbüs ve bu sûretle maksad-1 ihtilâlin husûlü zımnında katl-i nüfûs ef'âlini icrâya tasaddi etmişlerdir. Bunlardan Kara Ahmed rüfekasıyla birlikte bir müddet Pangaltı'da bir kahvede tarassudatta bulunarak bu sırada Nesim Roso Efendi'nin apartmanı kapıcısı ile apartman sahibinin adamı İbrahim Bey'den tahkîkât-1 lâzıme icra eyleyip ve bir aralık İstanbul'a geçmiş olan Kavaklı Mustafa ve Raif ile birleşmek üzere Beyoğlu'na gelir iken tesadüf eyledikleri merkûmândan Mahmud Şevket Paşa'nın katlini haber almışlardır. Kezâlik bunlardan Hakkı ile Ragıb bir müddet Karasu Efendi’nin öğle yemeğini yemekte olduğu noktada ${ }^{56}$ oturarak kendisini bekledikleri gibi bi'l-ahere Galata'da İstayn önlerinde tarassudatda bulundukları sırada bunlardan Hakkı polis tarafından derdest edilmiştir. Merhum Hakkı derdest olunduğu sırada Beyoğlu'nda Pire Mehmed Sokağı'ndaki bir ahbabını görmek üzere polislerden müsaade talep eylemiş ve merkumun bu suretle nereye gideceği anlaşılmak üzere kendisine müsaade verilerek bi'n-netice Pire Mehmed Sokağı'ndaki hânenin tarassuduna imkân 
hâsıl olmuştur.

Hakkı bu sırada mezkûr hanede bulunan Şevki Efendi ile Kâzım’a derdest olunduğunu söylemiş ve kendi izlerini gaib etmek üzere teslim olması hakkındaki ihtârına teberyyetle avdet ederek polise teslim olmuştur. Ve bu sırada da mezkûr haneye Mehmed Ali vürud etmiş ve evvelce arz olunduğu üzere merkum dahi mezkûr hâne dahilinde bi'l-müsâdeme derdest edilmiştir.

Kâzım Efendi'nin zât-1 âlîleriyle Cemal Bey ve bendeniz üzerine sevk eylediği diğer gruplar dahi aynı sûretle bir iş göremeyerek her biri bir tarafa savuşmuş ve bunların her biri pey-derpey der-dest olunmuşlardır. Muhtelif taraflarda tertip ve sevk olunan bu grupların ifâ-yı vazifeyi müteakib Beyoğlu'nda Pire Mehmed Sokağı'ndaki cem ‘iyyetin merkez-i icraatına avdet etmeleri mukarrer olduğu halde bunlara tevdi olunan vazâifi ifa edememeleri ve her tarafdan sıkı bir ta'kib-i tarassud altında kalmaları hasebiyle bi't-tab' bu ictima' akim kalmış ve Kâzım'ın zâten mevki-i icr'aya vaz' edemeyeceği muhakkak olan teşebbüsât-1 ahiresinin dahi icrasına imkân kalmamıştır.

Kâzım'ın tasavvurâtına nazaran buradan hareket olunarak saray-1 hümayuna gidilmek mukarrer bulunduğu ve bu sirada evvelce aralarında takarrür ettiği üzere Miralay Kemal ve Miralay Fuad ve Kaymakam Zeki beyler tarafından İstanbul Muhafızlığı ve Merkez Kumandanlığ gibi mevâkî-i mühimme elde edilmiş bulunacağı cihetle teşebbüsât-1 vâkı'anın kolaylıkla meydana çıkacağı ümit edilmekte idi.

Yukarıda izah olunan esbab tahtında akim kalan bu teşebbüs üzerine ve hanenin taht-1 ${ }^{57}$ tarassuda alınmasına binâen Kâzım Efendi mevkuf kalmış ve bi'l-ahere bu hanenin abluka edilmesi üzerine yanında tahassun etmiş olan rüfekasıyla birlikte der-dest olunmuşlardır.

Hânenin ne sûretle muhasara olunduğu ve merkûmûnun ne suretle der-dest edildiği evvelce arz olunmuş idi. Maznûnun-aleyhimin icra eylemiş oldukları vakayi'-i ahirenin tertibât-1 maddiye ve cihet-i icraiyesine aid bulunan bu tafsilâtdan başka cem'iyyetin ne gibi müessirat altında teşekkül ve icrâ-yı faaliyet eylediğini ve buna kimlerin ne dereceye kadar iştirak eylediklerini tedkik etmek icap eder. Yukarıda bir bende bahs ve beyan olunduğu üzere Damad Salih Paşa'nın Avrupa'dan celbine tavassut eylediği mebâliğ teşebbüsât-1 ahirenin esâsını teşkil etmektedir. Bu paranın tedâriki zımnında Muhib Bey’in Damad Salih Paşa nezdindeki teşebbüssâtı hüsn-i kabul edilmiş ve Avrupa'da bulunan Reşid Bey’e bu bâbda ayrıca müracaat olunarak kendisine mektup yazılmıştır.

Salih Paşa'nın ifâdât-1 mazbutasına nazaran bu müracaatın kabul edilmediği beyan edildiği halde gerek Muhib Bey’in ve Gözlüklü Emin Bey’in ve Aziz Nuri Efendi’nin bilhassa maznunlardan Mehmed Ali Efendi'nin ifadât ve i'tirâfâtıyla bu ifâdâtın aksi sabit olmaktadır.

Salih Paşa Muhib Bey tarafından vuku bulan bu müracaat-i ibtidaiyenin hüsn-i kabul edilmediği beyan edildiği halde bu müracaatların tekerrür ve tevâlîsinin ve cem ‘iyyetin her gûna umûr-1 husûsâtın kendisine ayrı ayrı tebliğ edilmekte bulunmasının câlib-i nazar-1 dikkat olduğunu arz ederim.

Bu cümleden olmak üzere gerek kendi ifâdâtından ve gerek bu ifâdâta muvâfık olarak Muhib Bey'in ve Mehmed Ali Efendi'nin beyânât-1 ahiresinden anlaşıldığı üzere bu hususda kendisine defaât ile müracaat vuku bulmuş ve her birinde umûr-1 cem'iyyete müteallik müzâkerât cereyan 
etmiş ve teklifat vuku bulmuştur.

Salih Paşa'nın diğer taraftan cem 'iyyetin tervic-i amâli ve hîn-i ihtilâlde sâyebîne müracaat ederek zât-1 hazret-i pâdişâhinin celb ve imâle-i efkârı hakkında taahhüdâtda bulunmuş ve bu bâbdaki taahhüdâtı gerek Mehmed Bey'in ${ }^{58}$ ve gerek Mehmed Ali Efendi'nin ve fazla olarak Aziz Nuri Efendi'nin ifâdâtından anlaşılmaktadır. Yine bu ahvâle inzimam ederek Damad Salih Paşa, Muhib Bey'in yakın zamanda bir inkılâp yapacağını (yapılacağını?) ve bu sırada birçok adamın katlonulacağını bildiğini beyan ederek bunu da Nuri Bey’in hanesinde Muhib Bey'in söylemiş olduğu ve Dördüncü Daire-i Belediye Reis-i sâbıkı Mustafa Bey’den işittiğini beyan eylemiş olduğu halde gerek Nuri Bey'den ve gerek Mustafa Efendi'den ayrı ayrı vuku bulan istizâhât neticesinde Muhib Bey'in Nuri Bey'in hanesinde bu vechile bir beyânatda bulunmadiğg sâbit olmuştur.

Prens Sabahattin Bey’in dahi tertîbât-1 vâkı'adan hâiz-i alâka ve münasebet olduğu cihetle bu bâbda mühim bir rol oynadığını tahkîkat-1 vâkı'a ile tamamen tezahür etmektedir.

Muhib ve Kâzım beyler Prens Sabahaddin Beyle bu mes'ele hakkında açıktan açığa görüşmüşler ve inkılâbı müteakip mevki'-i iktidâra getirecekleri kabinenin kimlerden mürekkeb olacağı hakkında arîz ve amik müzâkerât icra kılınmıştır. Bu da müzâkerâtda adeta pazarlık uymaması yüzünden bir müddet akim kalmış ise de bi'l-ahere Kâzım Efendi'nin Damad Salih Paşa ile münasebeti neticesinde ber-vech-i bâlâ bede' ve mübâşeret etmiş olduğu faaliyet-i ihtilâliyeden aynı zamanda Prens Sabahaddin Beyle dahi te'mîn-i istifade eylediğini yukarıda arz etmiş idim.

$\mathrm{Bu}$ müzâkere ve mülâkat Kemal Midhat Bey tarafından sevk ve idare olunmuştur. Ve Sabahattin Bey'in bu mes'elede Şerif Paşa kadar alâka-i maddiyesi olduğu cihetle bu def'aki i'tilâf hemen kolaylıkla vuku bulmuş, Sabahaddin Bey'in mevki-i sadarete getirilmesinden sarf-1 nazar edilmesi ile neticelenmiştir. Şurası ayrıca câlib-i nazar-1 dikkattir ki cürmünü tamamen ikrar ve i’tiraf etmiş olan maznûnun-aleyh Kâzım Efendi'ye bu bâbda bazı sualler sorulmuştur.

Bu sual ve cevâbı neticesinde tamamen taayyün etmiştir ki Kemal Midhat'ın akd ettiği bu i'tilâf Prens Sabahaddin Bey'in tamamen haber ve ma'lûmât ve rızası tahtında cereyan etmiş, Sabahattin Bey'in namina hareket eden Kemal Mithat Bey'in bu cereyandan Sabahaddin Bey'i haberdar ettiği tahakkuk etmiştir. Zaten Sabahaddin Bey namına hareket eden Kemal Midhat Bey'in bilâ-istizan Sabahaddin Bey'in hakk-1 sadaretinden vazgeçmesi bi't-tab' (bittabi) gayr-i kabil-i tasavvur bulunmaktadır. Şevki Efendi Kâzım grubuna iltihak etmiştir. Ve Şevki Efendi, faaliyet-i ihtilâliyesi(ni) bu vak'a sırasında bi-hakkın isbat eylemiştir. Kezalik bu cümleden olmak üzere Kemal Midhat Bey ile Kâzım Efendi arasında vakayi'-i ihtilâliye sırasında ecânibin te'mîn-i istirahat ve huzuru mes'elesi ve İstanbul ${ }^{59}$ asayişinin sûret-i idaresi dahi mevzu-1 bahs edilerek sefarethanelere birer nota verilerek keyfiyyetin bildirilmesi takarrür etmiştir. Kâzım Efendi'nin ifâdâtına nazaran bu notanın tanzim ve i’tası Kemal Midhat Bey’e terk edilmiştir. Kemal Midhat Bey bu bâbdaki vazifesini bir sûret-i ma'kûsede ifa etmiştir. Avusturya Sefarethanesi'ne i'ta olunup sefarethaneden bir sûreti ahz ve istihsal edilmiş olan bu nota vak'a-i cinaiyenin tertip ve icra edildiği Çarşamba günü tarihini ve "on saat kırk dakika” kelimelerini hâvîdir. Mündericâtında hükûmet aleyhine herçi-bâd-âbâd bir inkılâp ve ihtilâl icra olunarak bu fena idarenin hitâma erdirileceği cihetle limanda bulunan gemilerden asker ihrâcıyla asâyiş-i memleketin muhafazası menâfi-i mahalliye ve ecnebiye iktizâsından olduğu bildirilmektedir. Binâen-aleyh maznûnun- aleyhimin

$\begin{array}{ll}58 & \text { BOA, DH. KMS 63/63-9,1 } \\ 59 & \text { BOA, DH. KMS 63/63-10,1 }\end{array}$ 
bu vesile ile de ne fikir ve maksad tahtında hareket etmekte oldukları taayyün eder. Bundan evvel bir miktar bahs ve izah edildiği üzere Salih Paşa'dan celp ve tedârikine tevessül edilip cem'iyyet-i fesadiyenin müstenid-i icraatı olan mebâliğ Salih Paşa'nın tavassutuna binâen Reşid Bey ve Şerif Paşa'dan tedarik olunmuştur. Bu bâbdaki muhaberâta Pertev Tevfik Bey delâlet ederek bu bâbda mebâliğ-i mezkûre bu sûretle tedarik olunmuş ve Romanya'da Köstence'ye azimet eden Reşid Bey ile de ayrıca mülâkat olunarak esas-1 mes'ele takarrür ettirilmiştir. Ahiren bir ajansın tebligâtı cümlesinden olacağı üzere Reşid Bey'in Köstence'ye azimetini i'lân edip fakat bunun aile esbâbından ileri geldiğini beyan eylemiş olması ayrıca câlib-i nazar-ı dikkattir. Gümülcineli İsmail Bey dahi bu faaliyet-i ihtilâliyenin a'zâ-yı âmilesinden olup ordu ile temas ve münasebette diğerlerinden ziyade faaliyet ibraz eylemiş ve Pertev Tevfik Bey'in nezdinde daima toplanarak ihtilâl müzâkerâtına ve teşebbüssâtına bir sûret-i makalanede iştirak eylemiştir.

Tertibât-1 ihtilâliyeyi mevki'-i icrâya vaz' etmek üzere bazen erkân-1 harb zâbitânının te'mîn-i muavenet ve iştirâkine lüzum görerek bunun içün de Yüzbaşı Adil Efendi vâsıtasıyla erkân-1 harb miralaylarından Fuad Bey’e haber göndermiş ve mûmâ-ileyh dahi Kâzım ile teşrîk-i mesaî ile Miralay Kemal Bey'i dahi bu cem'iyyete celp ve da'vet etmiştir. Fuad Bey'in tanzim eylediği kroki ${ }^{60}$ ile mezkûr haneye gelmiş olan Kemal Bey ve Kaymakam Zeki dahi hazır olduğu halde ale'l-usul ve şekl-i mukarrer dairesinde tahlif edilmişlerdir. Ve yine orada takarrür eylediği üzere bunlardan Kemal Bey İstanbul Muhafizlığı ve Zeki Bey Merkez Kumandanlığı ve Fuad Bey Erkân-1 Harb Riyaseti gibi vazâifi kabul ve deruhde etmişlerdir. Bu sırada kendilerine cem 'iyyetin alâmet-i fârikası olan ma'hud mendillerden tevzi ve i'ta olunmuştur. Kezâlik maznunlardan Kasabın Fehmi'nin maznunlarla temas ve münâsebeti bulunacağını ve umûr-1 cem'iyyetle alakadar olacağı, Şeyhli Mustafa'nın Cemal Bey'in katline me'mur çetede ifâ-yıvâzifeye me'mur edildiği ve Jandarma Sadık'ın dahi diğer maznun Jandarma Kemal'in esliha ve cephanesini ketm ve ihfa eylediği ve Gözlüklü Emin Bey'in dahi gerek Salih Paşa'nın maznunlarla teması ve münasebetini te'min etmek ve bu sûretle Nazmi'yi Salih Paşa'nın nezdine i'zamına delalet etmek sûretiyle cem'iyyetin muharrik-i fesad olan eşhasından bulunduğu ve Süleyman Paşa-zade Adil Bey'in yine bu cem'iyyetin efrâd-1 faalesinden idüğü ve İzzeddin, Pertev Tevfik tarafindan sevk-i idare olunan faaliyet-i ihtilâliyeye iştirak eylediği ve şoför Mehmed ile şoför İsmail'in maznunlardan Abdurrahman ile bir def'a görüşerek zaman-1 vak'ada otomobilin istimini kesmek ve otomobili terk ederek firar eylemek gibi daima şübhe-i ahval irâe eylediği anlaşılmıştır.

Binâen-aleyh arz ve tafsil edilen teşebbüsât-1 ihtilâliye Reşid Bey ile Şerif ve bilhassa Salih paşaların muavenet ve ta'limatlarıyla Kâzım'ın tedarik ettiği avenesi vasıtasıyla idare ve icra eylediği tahakkuk eylemiştir. Bunlardan merbûten arz ve takdim edilen defterde henüz derdest edilemedikleri görülecek eşhas içün dâire bütün faaliyetiyle çalışmakda olduğu gibi burada bulunup henüz memâlik-i ecnebiyyeye firar edemedikleri taayyün etmekde olanların der-destine muvaffakıyet hâsıl olacağına kanaatim olduğunu arz eylerim. Ol bâbda emr ü fermân hazret-i men lehü'l -emrindir. Fi 7 Haziran 329

Polis Müdir-i Umûmîsi

Azmi” ${ }^{61}$

60 BOA, DH. KMS 63/63-1,1

61 BOA, DH. KMS 63/63-12 
Ek 2: İstanbul Polis Müdiriyet-i Umumiyesi tarafından hazırlanan Mahmut Şevket Paşa suikastını gösteren krokinin Türkçe transkripsiyonu şu şekildedir: ${ }^{62}$

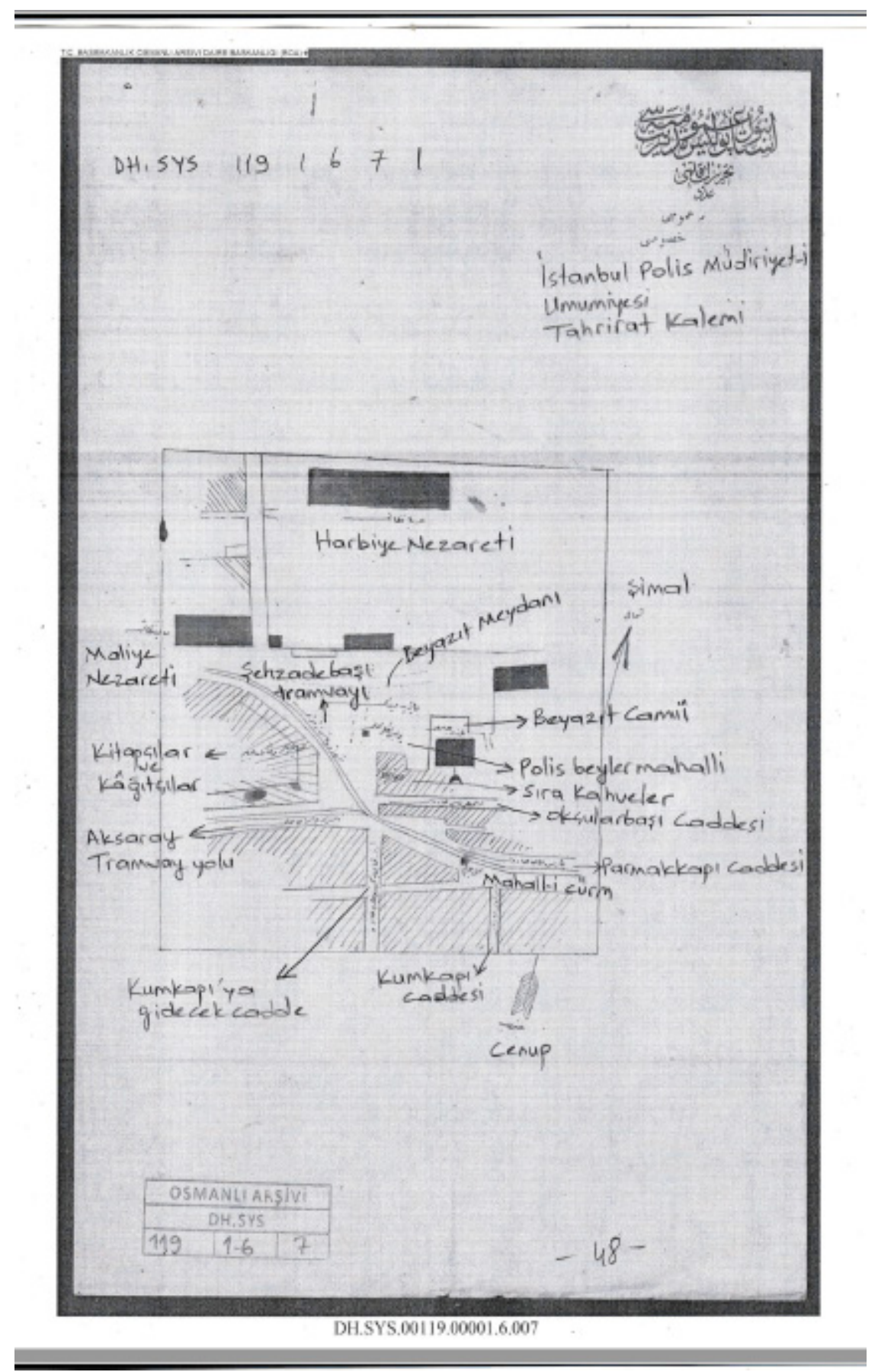


Ek 3: Yapılan yargılanmalar sonucunda ceza alan kişiler, cezaları ve yargılanma şekillerini içeren belge ${ }^{63}$

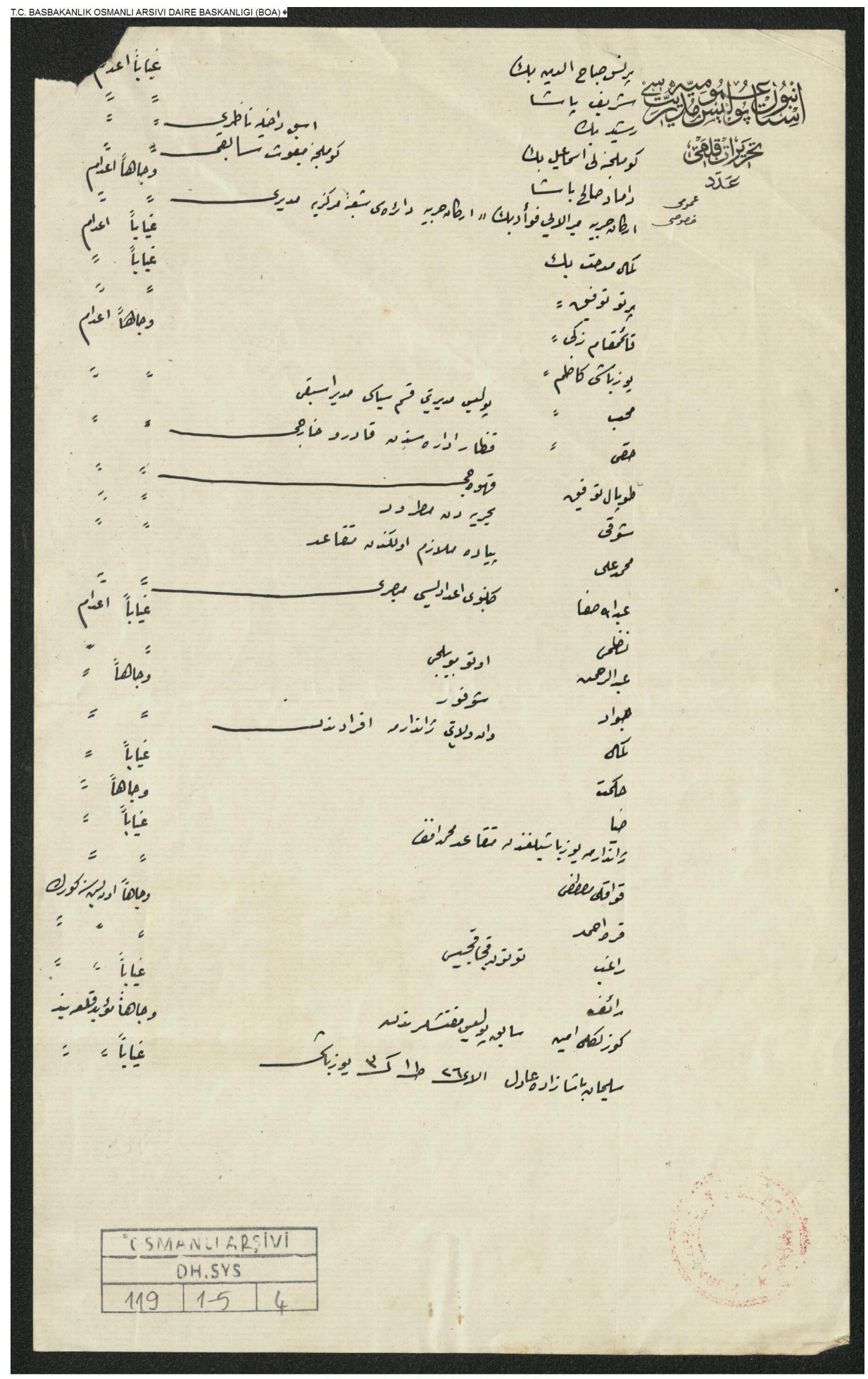

DH.SYS.00119.00001.5.004 